\title{
Seagrass and Submerged Aquatic Vegetation (VAS) Habitats off the Coast of Brazil: state of knowledge, conservation and main threats
}

\author{
Margareth S. Copertino ${ }^{1 *}$, Joel C. Creed ${ }^{2}$, Marianna O. Lanari ${ }^{1,3}$, Karine Magalhães $^{4}$, Kcrishna Barros $^{5}$, \\ Paulo C. Lana ${ }^{6}$ Laura Sordo ${ }^{6,7}$, Paulo A. Horta ${ }^{8}$
}

\author{
${ }^{1}$ Laboratório Ecologia Vegetal Costeira, Instituto de Oceanografia, Universidade Federal do Rio Grande - FURG \\ (Av. Itália, Carreiros. CEP 96203-900, Rio Grande, RS, Brasil) \\ ${ }^{2}$ Departamento de Ecologia, Universidade do Estado do Rio de Janeiro \\ (Rua São Francisco Xavier, 524. CEP: 20550-900, Maracanã, RJ, Brasil) \\ ${ }^{3}$ Programa de Pós-Gradução em Oceanografia Biológica, Universidade Federal do Rio Grande - FURG \\ ${ }^{4}$ Departamento de Biologia, Universidade Federal Rural de Pernambuco (UFRPE) \\ (Rua Dom Manoel de Medeiros, s/n, Dois Irmãos. CEP: 52171-900 - Recife, PE, Brasil) \\ ${ }_{5}^{5}$ Instituto de Ciências do Mar, Universidade Federal do Ceará \\ (Av. Abolição, 3207. CEP 60165-081, Fortaleza, CE, Brasil) \\ ${ }^{6}$ Centro de Estudos do Mar, Universidade Federal do Paraná \\ (Av. Beira-Mar, s/n. CEP 83255-979, Pontal do Sul, PA, Brasil) \\ ${ }^{7}$ Centro de Ciências do Mar, Universidade do Algarve \\ (Campus Gambelas, Faro. CEP: 8005-139, Portugal) \\ ${ }^{8}$ Departamento de Botânica, Universidade Federal de Santa Catarina \\ (Rua Eng. Agronômico Andrei Cristian Ferreira, s/n - Trindade. CEP: 88040-900 Florianópolis, SC, Brasil)
}

*Corresponding author: doccoper@furg.br/marga.copertino@gmail.com

Financial Support: This study was supported by the Brazilian Network for Coastal Benthic Studies - ReBentos (Programa SISBIOTA), Rede CLIMA and INCT for Climate Changes; sponsored by CNPq and FAPESP.

\section{Abstract}

Seagrass meadows are among the most threatened ecosystems on earth, raising concerns about the equilibrium of coastal ecosystems and the sustainability of local fisheries. The present review evaluated the current status of the research on seagrasses and submerged aquatic vegetation (SAV) habitats off the coast of Brazil in terms of plant responses to environmental conditions, changes in distribution and abundance, and the possible role of climate change and variability. Despite an increase in the number of studies, the communication of the results is still relatively limited and is mainly addressed to a national or regional public; thus, South American seagrasses are rarely included or cited in global reviews and models. The scarcity of large-scale and long-term studies allowing the detection of changes in the structure, abundance and composition of seagrass habitats and associated species still hinders the investigation of such communities with respect to the potential effects of climate change. Seagrass meadows and SAV occur all along the Brazilian coast, with species distribution and abundance being strongly influenced by regional oceanography, coastal water masses, river runoff and coastal geomorphology. Based on these geomorphological, hydrological and ecological features, we characterised the distribution of seagrass habitats and abundances within the major coastal compartments. The current conservation

\section{RESUMO}

Pradarias de gramas marinhas e vegetação aquática submersa (VAS) estão entre os ecossistemas mais ameaçados do planeta, gerando preocupação sobre o equilíbrio dos ecossistemas costeiros e a sustentabilidade das pescarias. A presente revisão avaliou o estado do conhecimento sobre as pradarias marinhas e VAS do Brasil, considerando as respostas das plantas às condições ambientais, e o possível papel da geomorfologia costeira e variabilidade climática sobre a distribuição e abundância das populações. Apesar do crescente aumento no número de publicações, a comunicação dos resultados ainda é relativamente limitada e destina-se principalmente ao público nacional ou regional. Como resultado, as pradarias de gramas marinhas da América do Sul raramente são incluídas ou citadas em revisões e modelos globais. A escassez de estudos em larga escala e de longo prazo, permitindo a detecção de mudanças na estrutura, abundância e composição dos habitats e espécies associadas, limita a investigação das comunidades no que diz respeito aos efeitos potenciais das mudanças climáticas. Pradarias marinhas e VAS ocorrem ao longo de toda a costa brasileira, mas a distribuição e abundância das espécies são influenciadas pela oceanografia regional, massas de água costeiras, descarga de rios e geomorfologia costeira. Com base nas características oceanográficas, geomorfológicas, hidrológicas e ecológicas, o estudo discutiu a distribuição e abundância dos habitats vegetados pelas distintas regiões costeiras. O estado de conservação das pradarias marinhas 
status of Brazilian seagrasses and SAV is critical. The unsustainable exploitation and occupation of coastal areas and the multifold anthropogenic footprints left during the last 100 years led to the loss and degradation of shoreline habitats potentially suitable for seagrass occupation. Knowledge of the prevailing patterns and processes governing seagrass structure and functioning along the Brazilian coast is necessary for the global discussion on climate change. Our review is a first and much-needed step toward a more integrated and inclusive approach to understanding the diversity of coastal plant formations along the Southwestern Atlantic coast as well as a regional alert the projected or predicted effects of global changes on the goods and services provided by regional seagrasses and SAV.

Descriptors: Seagrasses, SAV, Distribution, Antropogenic impacts, Global climate change, Climate variability.

\section{INTRODUCTION}

Seagrass meadows and coastal submerged aquatic vegetation (SAV) constitute complex habitats that influence the physical, chemical and biological characteristics of coastal environments, acting as ecological engineers and providing a number of services to marine systems and human populations (ORTH et al., 2006). These habitats are dominated by rooted plants that primarily colonize soft marine sediment on shallow coasts under low-to-moderate energy (KEMP et al., 2004; DENNISON et al., 2008). Seagrasses are a particular and homogeneous group (phylogenetic related) of rooted and flowering plants confined to the estuarine and marine environment that are able to live and complete their life cycle under submerged and haline conditions (DEN HARTOG; KUO, 2006). SAV are plants that live below or at the water surface, and it is a general term for prairies within estuaries and freshwater environments; it includes seagrasses, freshwater grasses and macroalgae species (KEMP et al., 2004; DENNISON et al.; 2008). Recognizing that both seagrass meadows and SAV have similar ecological functions, are affected by similar physical drivers and are highly threatened by anthropogenic impacts, this review will use the two terms interchangeably. The capacity of SAV and seagrasses to physically and chemically engineer their environment and to supply coastal protection - among the many services and benefits human populations may obtain from the ecosystem functions (KOCH, 2001; MILLENNIUM ECOSYSTEM ASSESSMENT, 2005) - has been largely evidenced in European, Australian and U.S. coastal regions. The plant canopy buffers the impact of waves, protecting e VAS no Brasil é extremamente crítico. A exploração insustentável e ocupação da zona costeira durante os últimos 100 anos conduziram à rápida degradação e perda de muitos dos habitats bentônicos marinhos e costeiros, outrora favoráveis para a ocupação da vegetação aquática. $\mathrm{O}$ conhecimento sobre os padrões e processos que regem a estrutura e o funcionamento destas populações e comunidades é fundamental para prever e compreender os efeitos das mudanças climáticas. A presente avaliação é um primeiro passo, necessário para uma abordagem mais integrada e inclusiva sobre a diversidade de formações vegetais costeiras ao longo do Atlântico Sudoeste, bem como um alerta regional a respeito dos efeitos previstos das mudanças climáticas das mudanças globais sobre os produtos e serviços ecossistêmicos prestados pelas pradarias marinhas.

Descritores: Pradarias marinhas, VAS, Distribuição, Impactos antrópicos, Mudanças climáticas globais, Variabilidade climática.

the coast and shallow bottoms from erosion. By reducing current velocity, the plant canopies promote the deposition of suspended matter, increasing water transparency within and adjacent to the meadows. The rhizome net traps and stabilizes the sediments, contributing to sediment accretion, the accumulation of organic matter and carbon sequestration. Seagrasses and SAV improve water quality by oxygenation and by removing excess nutrients and other pollutants from river and runoff inputs (KOCH, 2001; SHORT et al., 2007; BARBIER et al., 2001). Due to their structural complexity and high primary production, they provide food and nursery habitats for many invertebrates and fish; many economically important fish and shellfish species depend on seagrass beds during critical stages of their life cycle (ORTH et al., 2006; WAYCOTT et al., 2009). Seagrass and SAV habitats also provide forage for many aquatic birds and endangered species, such as seahorses, sea dragons, sharks, sea turtles, dugongs and manatees (BJÖRK et al., 2008; HEMMINGA; DUARTE, 2000). They also have important aesthetic and cultural values, providing leisure and sustaining tourism activities such as snorkeling, diving, fishing and fauna watching (BJÖRK et al., 2008). In the past they have been used as mattress filling, roof covering, house insulation, garden fertilizers (BJÖRK et al., 2008) and in traditional medicine (DE LA TORRE-CASTRO; RÖNNBÄCK, 2004), as well as for spiritual uses (LAUER; ASWANI, 2010).

Together with mangroves and salt marshes, seagrass meadows are among the largest carbon sinks in the ocean - more than half of sequestered carbon is located beneath these systems despite their covering only $0.5 \%$ of the 
seabed (MCLEOD et al., 2011; FOURQUREAN et al., 2012; DUARTE et al., 2013). Their associated sediments contain 2 to 15 times more carbon per hectare than terrestrial soils (FOURQUREAN et al. 2012). Furthermore, the rate at which these coastal systems sequester carbon is 10 to 50 times greater than the rate of carbon sequestration by terrestrial forest systems, and this carbon can be sequestered by the climatic system on timescales of centuries or even millennia. Therefore, seagrass meadows play a fundamental role in the global carbon cycle with the potential to mitigate climate change (DUARTE et al., 2013). Within this scenario, protecting and restoring seagrass meadows may be used in the near future as an offset in carbon budgets (LOVELOCK; MACALLISTER, 2013). The economic value of the world's seagrass meadows has been estimated (COSTANZA et al., 1997; LARKUM, 2006; UNSWORTH et al., 2010; BLANDON et al., 2014; VASSALO et al., 2014; COSTANZA et al., 2014; TUYA et al., 2014), and it may vary from US\$ 968 to US\$ 2 million $\mathrm{ha}^{-1} \mathrm{y}^{-1}$ depending on the region, included services and methodology applied. Globally, seagrasses can provide ecological services worth more than US\$ 20 billion a year (ORTH et al., 2006), a value 33 and 23 times higher, respectively, than the average oceanic and terrestrial values, being 3 times greater than that of coral reefs and 10 times greater than that of tropical forests (BJÖRK et al., 2008). These values should increase considerably when the value of carbon sequestration is added in the near future.

The global distribution and abundance of seagrasses and SAV has changed gradually over time (the last 70-80 million years) in response to sea-level changes, physical modification of coastlines, changes in atmospheric carbon dioxide concentration ( $\mathrm{ppm} \mathrm{CO}_{2}$ ), sea surface temperature (CROWLEY, 1990; BERNER; KOTHAVALA, 2001) and herbivore-seagrass interactions (DOMNING, 2001). While spreading and undergoing continued change and adaptation to regional environmental drivers, seagrass habitats have been modified by current changes to the coastal zone resulting from increased human pressures and recent changes in the global climate. Over the last 40 years, seagrass losses have increased almost tenfold in both tropical and temperate regions, suggesting that seagrasses are facing a global crisis (ORTH et al., 2006). It is believed that at least $~ 30 \%$ of their known extent in terms of area has disappeared since the end of the $19^{\text {th }}$ century (WAYCOTT et al., 2009), a number that is certainly underestimated because it was mainly based on European, North American and Australian studies. The loss rates have accelerated since 1990 (from 2\% to more than 7\% $\mathrm{yr}^{-1}$ ), placing seagrass meadows among the most-threatened ecosystems on earth. Because seagrasses, known as "coastal canaries" (ORTH et al., 2007), are good indicators of water quality and biological health, their reduction and loss are raising concerns about systems' equilibrium and the sustainability of local fisheries (LARKUM et al., 1989). This decrease disrupts important linkages between seagrass meadows and other habitats (HECK et al., 2008), and their ongoing decline is likely to produce much more far-reaching and long-lasting impacts than the loss of the meadows themselves.

Many seagrass species are highly vulnerable to global climate change, mainly due to the effects of the increase in atmospheric and sea surface temperature, sea level rise (causing salinity intrusion, changes in tides, currents and depth of light penetration), increases in the frequency and intensity of extreme events and ocean acidification (see SHORT; NECKLES, 1999; DUARTE, 2002 for reviews). In the mid- or long-term, there will be impacts on distribution abundance, population structure and communities, some of which have already been registered (SHORT; WYLLIEECHEVERRIA, 1996; SHORT et al., 2006; BJÖRK et al., 2008; CONNOLLY, 2009; WAYCOTT et al., 2009). Changes in seagrass ecological functions and connectivity, caused by both the direct and indirect effects of climate change, will echo throughout adjacent marine ecosystems in the midand long-term (SHORT; WYLLIE-ECHEVERRIA, 1996; ORTH et al., 2006; MARTINS et al., 2012); sooner or later, this will affect ecological services, such as coastal protection and fishing resources. Such threats may also compromise the way of life of many traditional communities associated either directly or indirectly with seagrasses (CULLENUNSWORTH et al., 2014).

While hundreds of studies about the changes in seagrass abundance can be retrieved from a rapid search of peerreviewed literature, most of them are limited to North America, Europe and Australia (see WAYCOTT et al., 2009 for a review). In contrast, there is a paucity of studies or records about seagrass losses or changes in South America (SHORT et al., 2006; COPERTINO; SEELIGER, 2010; MARQUES et al., 2015) despite its highly populated coastal region. Approximately $25 \%$ of the Brazilian population lives by the coast (more than 512 cities, including 13 metropolitan regions). The Brazilian coast is exposed to environmental problems similar to those experienced by both developed and developing countries (GARRETA; ALVES, 2003). From 1500 to the present, the major impacts have been deforestation, intensive boating activity, destructive anchoring, coastal construction, land reclamation, agricultural runoff, the direct destruction of salt marshes and mangrove forests, marina and 
port developments, aquaculture expansion, and coastal road constructions, among many others (DIAS et al., 2012). In addition, inadequate knowledge and ambiguous perceptions about the importance of seagrasses and SAV have led to a current lack of specific environmental policies.

The total extent of SAV and seagrass meadows along the Brazilian coast is unknown. The extent of these habitats has been roughly estimated at 20,000 hectares by CREED (2003), who summed up the few most-studied sites for which the areas were then known (Patos Lagoon Estuary in Rio Grande do Sul; Araruama Lagoon in Rio de Janeiro; Itamaracá in Pernambuco; Abrolhos National Park in Bahia). However, this is surely an underestimate because the $9000 \mathrm{~km}$-long linear Brazilian coastline has only been partially mapped to date. In addition to their irregular spatial distribution, seagrasses are highly dynamic and variable on distinct temporal scales. The climatic, hydrological and oceanographic variability along the Brazilian coastline can drive the significant changes in meadow extension and abundances observed over the years and decades (e.g., SHORT et al., 2006; COPERTINO; SEELIGER, 2010; SORDO et al., 2011; BARROS et al., 2013; MARQUES et al., 2015).

The present review aims, therefore, to evaluate the current status of seagrasses and coastal SAV research in Brazil in terms of plant responses to environmental conditions, the indications of change in the distribution and abundance of meadows and the possible role of climate variability (e.g. ENSO, extreme events) and climate change. This study is thus the first analysis of the potential effects of climate change on Brazilian SAV coastal communities. A number of recommendations and guidelines for future research are also presented in the light of their relevance to decision-makers and society as a whole.

\section{MATERIAL AND METHODS}

The authors reviewed all research areas and topics (morphology, taxonomy, biochemistry, physiology, ecology, biogeochemistry etc.) available in the literature on Brazilian seagrasses, including associated fauna and flora, through Web of Knowledge, Scopus and Google Scholar. In addition to peer-reviewed articles, we also searched for information in unpublished or published technical reports, conference abstracts, monographs, dissertations, and thesis. We also undertook searches using national and regional databases such as Plataforma Lattes (maintained by the Conselho Nacional de Desenvolvimento Científico e Tecnológico - http://attes. cnpq.br/), Portal de Periodicos CAPES (maintained by the Coordenação de Aperfeiçoamento de Pessoal de Nível Superior - http://www.periodicos.capes.gov.br/) and the Scientific Electronic Library Online - http://www.scielo.org/). Brazilian researchers, working on benthic ecology, phycology, aquatic plants as well as coastal geomorphology, were also contacted to contribute information on seagrass occurrence and abundance. A database on Brazilian seagrasses was built with information on georeferenced occurrences, distribution, abundance, reproduction and other ecological parameters; abiotic (water and sediment) parameters; and associated flora and fauna. We performed metrics and graphical analyses by classifying and comparing the studies according to their spatial and temporal scopes, research topics, species analyzed, and date and source of publication. We discussed the distribuition of seagrass habitats as a function of coastal geomorphology and oceanography, within the context of the distintict Brazilian coastal compartments and landscapes (DILLENBURG et al., 2009; DOMINGUEZ, 2009; MUEHE, 2010).

The international literature on the impacts of climate change on seagrasses and submerged aquatic vegetation was reviewed, including the impacts of climate change on the Brazilian climate and coastal zone. We prioritized studies focused on occurring species and their distribution and on how climatic and water parameters affect species physiology and reproductive biology, population parameters and community ecology. The relevant information was integrated to discuss the vulnerabilities of Brazilian seagrass meadows to climate variability, climate change (mainly global warming) and anthropogenic impacts.

\section{RESULTS AND DISCUSSION}

\section{SEAGRASS STUdies IN BRAZIL: A METRIC AP- PROACH}

Compared with most coastal benthic ecosystems (mangroves, coral reefs, rocky shores and sandy beaches), Brazilian seagrass beds are poorly studied (BARROS et al., 2013). Despite more than 200 registered database items mentioning seagrasses in Brazil, the authors found no more than 120 publications including articles, thesis and book chapters from 1957 to 2015. Most studies were concentrated in the states of Pernambuco (PE), Rio de Janeiro (RJ) and Rio Grande do Sul (RS) (Figure 1). We analyzed the advance and progress made in knowledge during the last several decades. Before the 1970s, studies were limited to species occurrence and qualitative descriptions of the plants and environment (e.g., CAFRUNI et al., 1978; DEN HARTOG, 1970). During the 1980s, botanical and auto-ecological 
studies were more common (e.g., LACERDA; RESENDE, 1986; KOCH; SEELIGER, 1988; COSTA; SEELIGER, 1989), whereas papers on population ecology and ecophysiology increased during the 1990s. From then on, there was an increase in community studies, with very few ecosystem approaches (e.g., SILVA; ASMUS, 2001). The steady increase in the number of seagrass studies during the last few decades, particularly after the 1990s, is a trend observed around the world (Figure 2). Today, we are in a phase where reviews, data compilation, integrated studies and projects are finally being prioritized. Approximately $82 \%$ of the studies were classified as only descriptive, $8 \%$ were categorized as experimental and/or modeling and
10\% were reviews (Figure 3a). Most of the work focused on marine angiosperms and their associated fauna, with few studies investigating the occurrence of epiphytes and other associated primary producers (Figure $3 b$ ). In addition, less than half of these works simultaneously assessed the effects of environmental variables on the flora and fauna. Among the species of phanerogams that occur along the Brazilian coast, Halodule wrightii and Ruppia maritima are the most studied (Figure 3c), reflecting their wider distribution and higher abundance on the Brazilian coast.

Analyses of temporal variability in abundance and distribution of seagrass beds and associated fauna have been more common (Figure 3d). Seasonal analyses (as

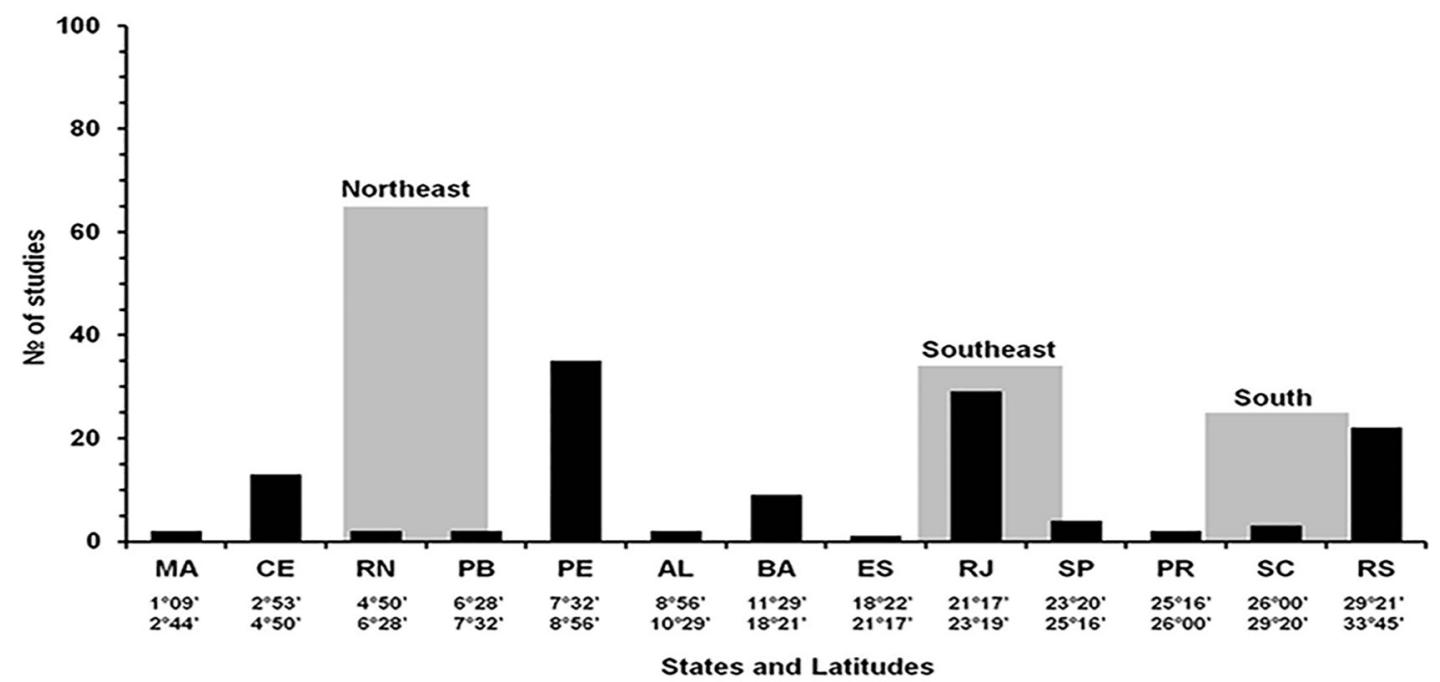

Figure 1. Number of publications (articles, thesis, dissertations, book chapters) containing information about seagrass habitats across the coastal latitudinal range of Brazil, counted per geographic region (grey columns) and federal state (black columns).

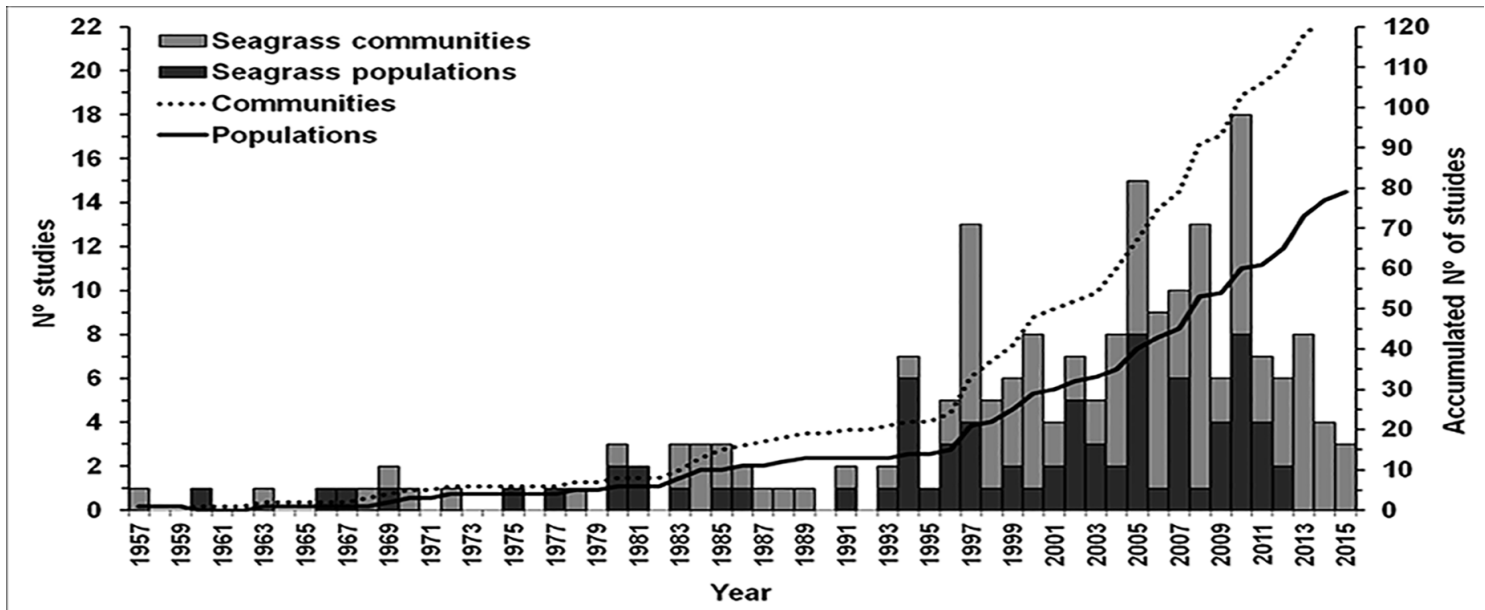

Figure 2. Number of yearly publications (articles, thesis, dissertations, book chapters) containing information about Brazilian seagrass habitats, accounting for studies that include only seagrass species (populations, black columns) and the studies which include the associated flora and/or fauna (communities, grey columns), since the first published studies in 1957. 

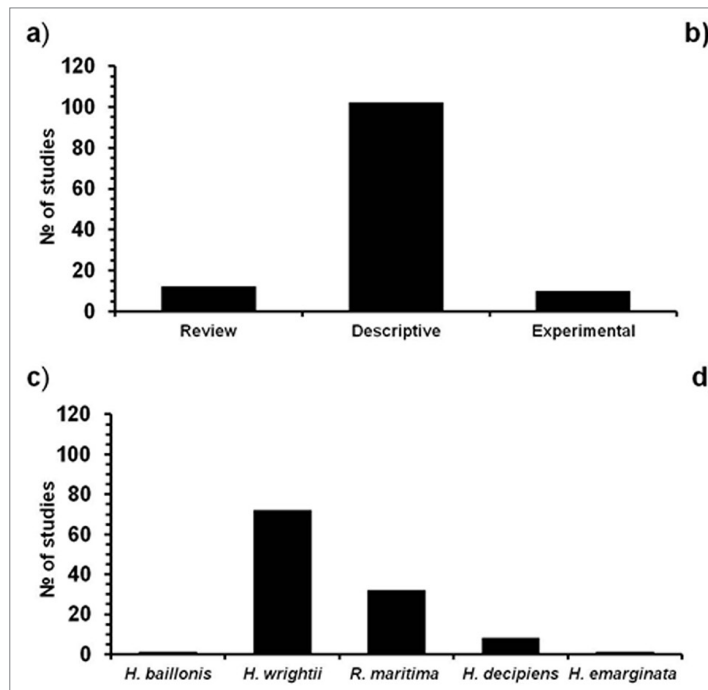

b)

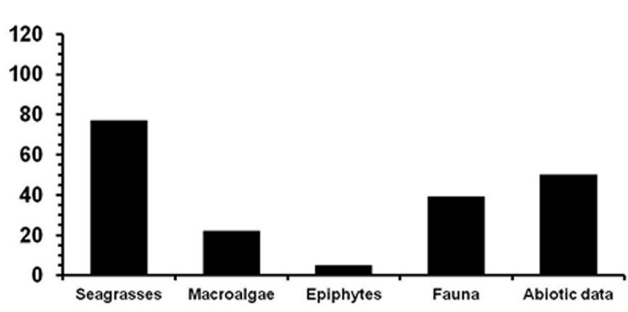

d)
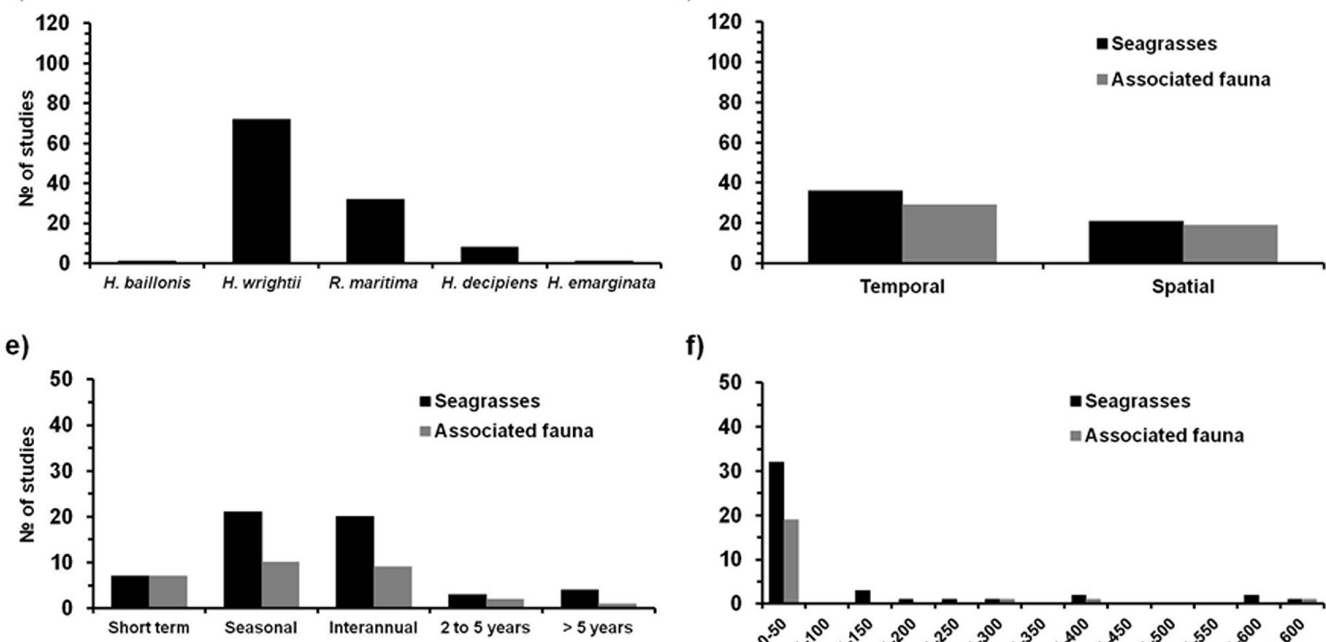

g)

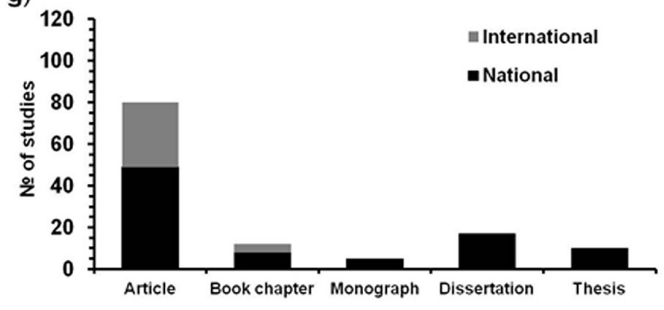

f)

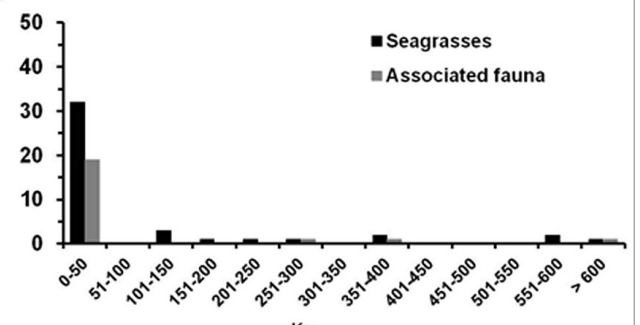

h)

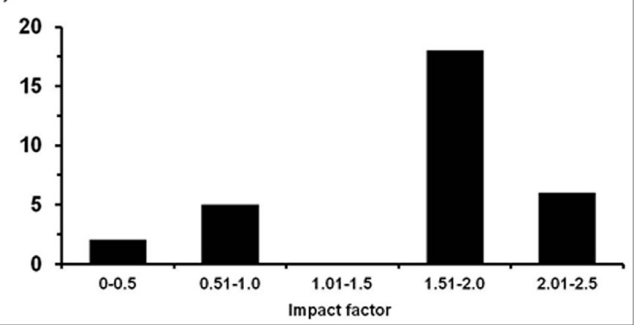

Figure 3. Scientometric analysis of Brazilian seagrass publications according to different criteria. Studies were classified according to their (a) methodological approach, (b) studied taxonomical/ecological groups and (c) target seagrass species. Few studies analyzed (d) temporal and spatial variability, which were performed at different (e) temporal and (f) spatial scales. The number of studies per (g) publication source and (h) the journal impact factor of the international articles are given.

between seasons or wet-dry seasons) and interannual (1-2 year) studies of the plants dominate (Figure 3e). Shortterm (a few months), seasonal and interannual studies are also the most common for seagrass-associated fauna. Most studies are local or of a small scale (0-50 km) (Figure $3 \mathrm{f})$.

Approximately half of the retrieved references are peerreviewed articles, the remainder being distributed among book chapters, theses, dissertations and monographs (Figure $3 \mathrm{~g}$ ). Most peer-reviewed articles have been published in indexed national journals. Less than half of the peer-reviewed articles were published in international journals with impact factors varying between 1.51 and 2.5 (Figure $3 \mathrm{~h}$ ).
This current scenario shows that despite the increase in the number of studies, communication of the results is still relatively limited and mainly addressed to a national or regional public. The predominance of descriptive, local and short-term studies provides basic knowledge of the composition and structure of submerged angiosperm prairies in Brazil. However, the scarcity of large-scale and long-term studies, which would allow the detection of changes in the structure, abundance and composition of seagrass habitats and associated species, still hinders the investigation of such communities with respect to the potential effects of climate change. 


\section{SPECIES OCCURRENCE AND DISTRIBUTION}

Seagrasses (sub-class Alismatidae) are distributed among five major family groups: Zosteraceae, Posidoniaceae, Cymodoceaceae (all species in these groups are seagrasses), Hydrocharitaceae (with 3 true seagrasses), Ruppiaceae and Zanichellaceae (these last two contain true and euryhaline seagrasses) (WAYCOTT et al., 2002). Compared with terrestrial plants and macroalgae, seagrasses present low diversity, with approximately 12 genera and more than 60 species (DEN HARTOG; KUO, 2006). Including the euryhaline species, the authors counted 76 species distributed across 15 genera.

Although eleven species of seagrasses are currently reported for the Tropical Atlantic (SHORT et al., 2010), the consensus is that only five occur along the Brazilian coast, as follows: Halophila baillonis Ascherson, Halophila decipiens Ostenfeld (Hydrocharitaceae), Halodule wrightii Ascherson, Halodule emarginata Hartog (Cymodoceaceae) and Ruppia maritima Linnaeus (Ruppiaceae) (OLIVEIRA et al., 1983; CREED, 2003) (Figure 4). Ruppia maritima has the widest distribution, ranging from Maranhão State $\left(2^{\circ} \mathrm{S}\right)$ to Rio Grande do Sul State $\left(33^{\circ} \mathrm{S}\right)$, but it is confined to shallow areas (20 $\mathrm{cm}$ to $3 \mathrm{~m}$ depth) in estuaries, coastal lagoons, fishponds, mangrove areas, salt marshes and salt ponds, growing under conditions from low salinity to hypersaline.
Halodule is associated with shallow habitats (less than 10 $m$ depth) with little freshwater input, such as reefs, macroalgal beds, coastal lagoons, sandy beaches and soft-bottom areas and nearby mangrove areas with little salinity fluctuation. $H$. wrightii has the widest distribution along the marine coastline, ranging from the states of Piauí $\left(2^{\circ} \mathrm{S}\right)$ to Santa Catarina $\left(27^{\circ}\right.$ S) (OLIVEIRA et al., 1983; FERREIRA et al., 2014). The occurrences in the Santa Catarina state have only recently been reported, suggesting a possible poleward expansion of this tropical species (FERREIRA et al., 2014). Being a widespread tropical species, with a high light requirement, $H$. wrightii is more abundant in Northeast Brazil, where average temperatures are higher. In Southern Brazil the species reaches the limit of its distribution at Florianópolis, occurring in small patches with reduced biomass, and to date, in one shallow estuarine system. The reduction in abundance results from changes in density and morphometric parameters. These changes in abundance are also observed to depend on wave exposition and sediment stability. H. emarginata is restricted to the tropical region between Ceará $\left(3^{\circ} 49^{\prime} \mathrm{S}\right)$ and São Paulo (23 45') (OLIVEIRA et al., 1983). The taxonomy of $H$. emarginata (supposedly a species endemic to Brazil) is uncertain, and there are many doubts about the validation of this taxon. This species is identified mainly by its biometric characteristics, especially the leaf tips, but genetic studies are still needed (BARROS et al., 2013).

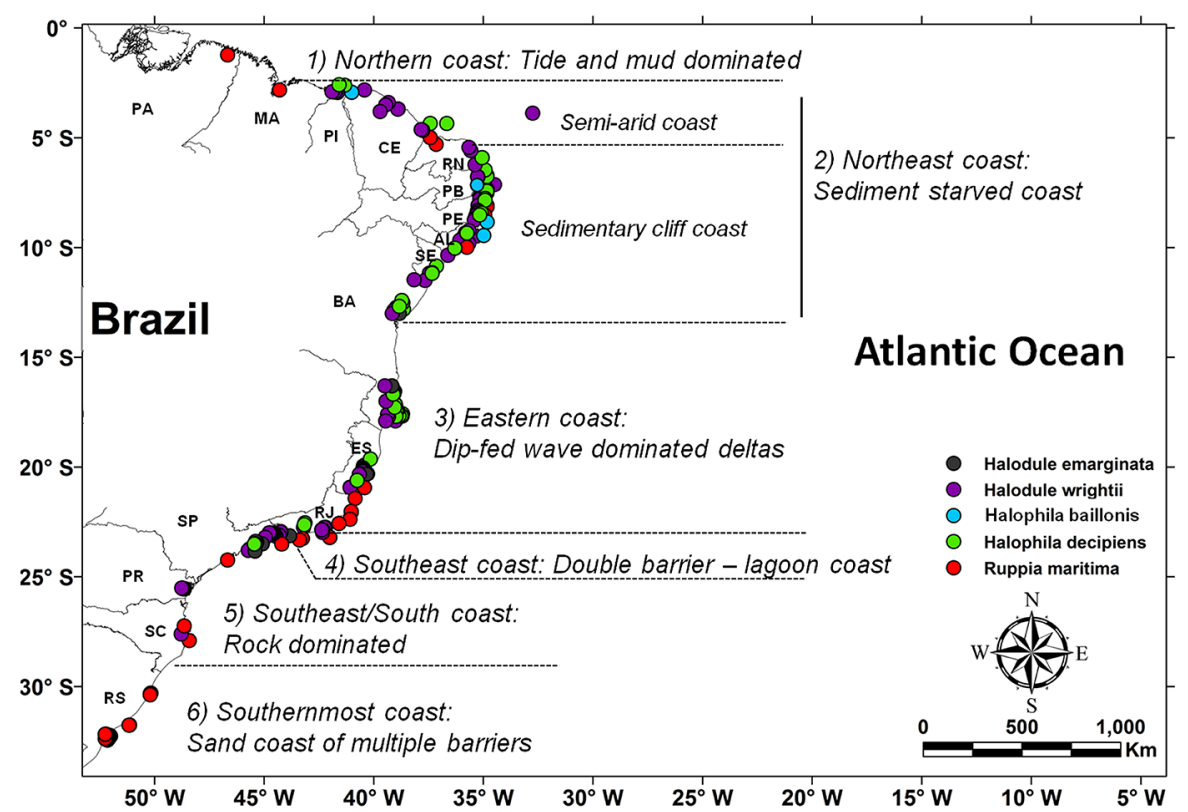

Figure 4. Distribution of the seagrass habitats and species along the coast of Brazil based upon all the existent records, in each coastal compartment. The coastal compartments were classified and characterized by DOMINGUEZ (2009) and MUEHE (2010), according to geomorphological, oceanographic and hydrological aspects. 
Halophila decipiens is restricted to the tropical region associated with riverbanks, deeper and shallow reefs, macroalgal and maerl beds and deeper, soft-bottom, vegetated areas. Having a more delicate form with lessdeveloped rhizomes, the species is more suited to calm waters. The lower light requirement allows this species to occur at depths down to $85 \mathrm{~m}$ (DEN HARTOG, 1970). H. baillonis was registered in 1980 and 1988 in the state of Pernambuco, (surrounding Santa Cruz Channel, 9 45' S) (DEN HARTOG, 1972; OLIVEIRA et al. 1983), but it was not found again for at least three decades (BARROS et al., 2013). Recently, the species has been reported on the northeastern coast of Brazil, between Piauí (Cajueiro da Praia, $2^{\circ} 55^{\prime} \mathrm{S}$ ) and Paraíba (Barra de Mamanguape, $\left.6^{\circ} 47^{\prime} \mathrm{S}\right)$, with at least two areas of well-established beds (BARROS et al., 2014; MAGALHÃES et al., 2015).

\section{COASTAL GEOMORPHOLOGY AND SEAGRASS}

\section{HABITAT DISTRIBUTION}

The Brazilian coast extends for 9,200 km (islands not included) from $4^{\circ} \mathrm{N}$ to $33^{\circ} \mathrm{S}$ with a very diverse suite of a coastal environments that evolved during the Quaternary period in response to changes in climate and sea level (DOMINGUEZ, 2009). Brazil has one of the world's most extensive river systems, with eight major drainage basins, all of which drain into the Atlantic Ocean. It rains all year round along the coastal zone, with the exception of northern Brazil where up to six dry months are observed (DOMINGUEZ, 2009). The tidal range progressively increases from south $(<1 \mathrm{~m})$ to north $(>6 \mathrm{~m})$ (SALLES et al., 2000). The major mechanisms of wave formation are intrinsically associated with the cold fronts, and the trade winds and wave heights average 1-2 $\mathrm{m}$ with periods of 5-7 $\mathrm{s}$. Because of these different mechanisms of wave formation, the central portion of the Brazilian coastline is subjected to two competing wave systems: east-northeastern and south-southeastern waves, with important implications for sediment dispersal (DOMINGUEZ et al., 2006).

The interaction of the geological background, sea level history, sediment supply, present climate (temperature, wind speed and precipitation) and associated oceanographic processes (waves and coastal currents) has contributed to the development of the different landscapes along the Brazilian coastline (DOMINGUEZ, 2009). There is a great variety of environments such as macrotidal plains covered by mangrove forests in the north; semi-arid coasts, bordered by Tertiary cliffs and delta-like coastal plains on the central coast; and wave-dominated environments in the south, either characterized by dissipative beaches at the border of the Late Quaternary coastal plain or rocky shores and eventually interrupted by reflective-to-intermediate pocket beaches (DOMINGUEZ, 2009; MUEHE, 2010; DIAS et al., 2012). Based on these relatively unique characteristics, the major coastal typologies or compartments present in Brazil have been described by DOMINGUEZ (2009) and MUEHE (2010).

Seagrass meadows and SAV occur all along the Brazilian coast (Figures 4 and 5), but species distribution, abundance and dynamics are affected by physical drivers, particularly the coastal geomorphology, oceanography and regional climate and hydrology. Based on the assumption that these factors are good predictors of seagrass distribution and abundances, we used DOMINGUEZ's (2009) coastal typologies and MUEHE's (2010) coastal compartments to characterize the Brazilian seagrasses (Figure 4). For this, we used the published and unpublished (personal communications and our own data) information about the dominant species and their abundances (cover, densities and biomass), depth of occurrence and associated flora and fauna. This approach is also useful for predicting the vulnerabilities of Brazilian seagrasses to climate change because each of those coastal compartments are exposed to different types and levels of impacts (MUEHE, 2010).

\section{1) The Northern coAst: TIDE AND MUD- DOMINATED}

The northern Brazilian Coast (1,200 km long) receives the largest volume of sediment on the entire coast of Brazil because of the Amazon River and other associated rivers (e.g., Tocantins and Parnaíba; DOMINGUEZ, 2009). It has a wide continental shelf (up to $300 \mathrm{~km}$ wide) and is controlled by macrotidal processes ( $>4 \mathrm{~m}$, up to 6.3 within estuaries), with wide estuary mouths and short and narrow barriers (SOUZA-FILHO et al., 2009). The region holds the largest mangrove system in the world and the gorge of the largest river in length, water and sediment discharge, the Amazon River (SOUZA-FILHO, 2005). It has a tide-muddominated coast to the west (Amapá-Guyanas) and a tidedominated mangrove coast to the east (Pará-Maranhão) (DOMINGUEZ, 2004). No seagrass meadows have yet been registered on the shore or within the large estuaries. We believe that the combined effects of very high fluvial discharge, mud deposition, turbid waters and macrotidal regime make the coastal region highly unsuitable for the establishment of seagrass meadows. However, there are 


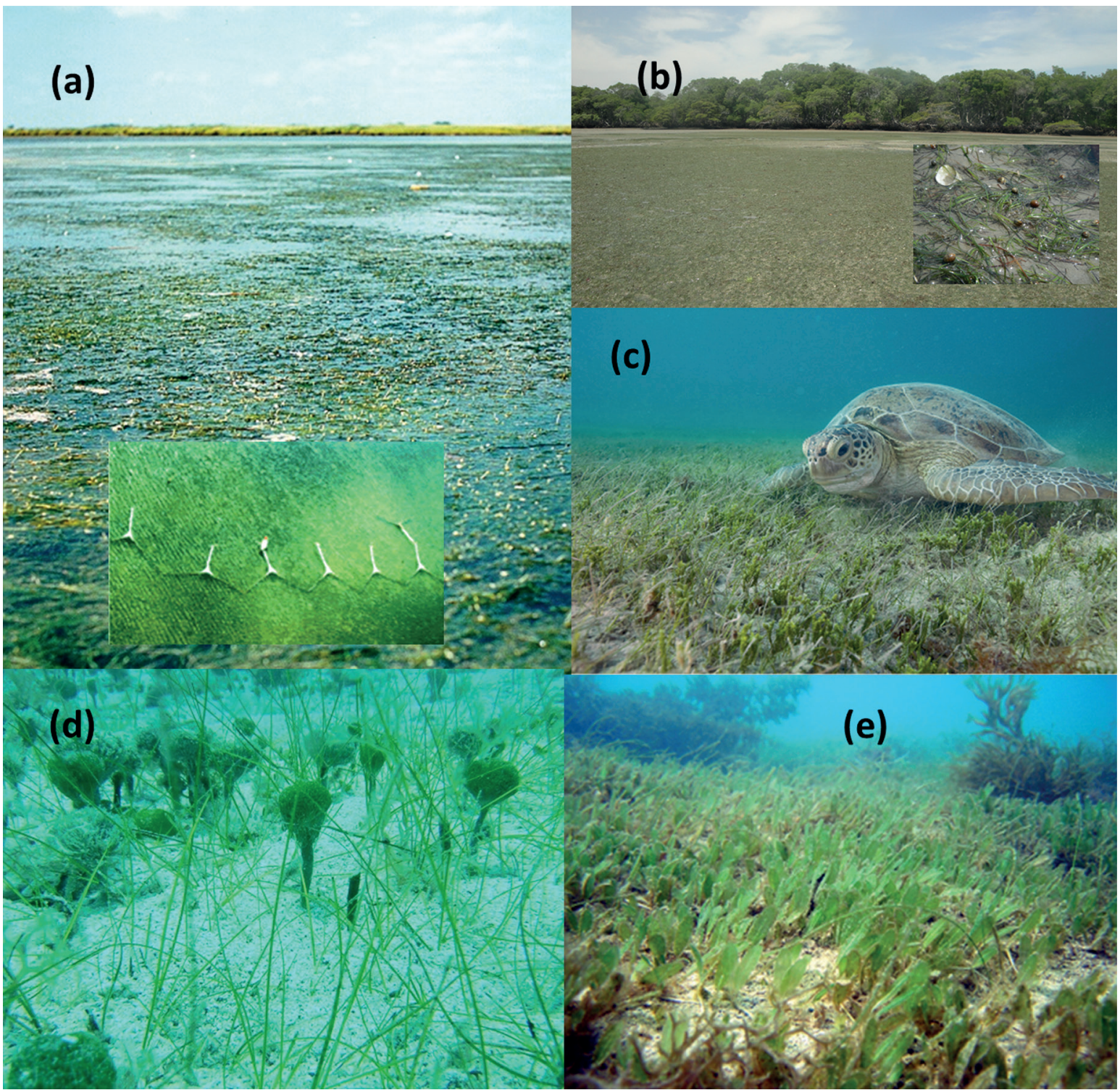

Figure 5. Seagrass habitats and species. a) Meadows of Ruppia maritima in very shallow areas $(<1.0 \mathrm{~m})$ of Patos Lagoon estuary (RS), with salt marshes at the back. The insert shows an aerial view of shrimp fishing nets ("rede de aviãozinho") fixed on vegetated bottoms. b) Intertidal meadows of Halodule sp in Macapá River estuary (Parnaíba Delta, PI) during low tide, with mangroves at the back. c) Green turtle (Chelonya mydas) resting on mixed seagrass-macroalgae stands in Abrolhos National Park (BA). d) Stands of Halodule wrigthii and calcareous macroalgae (Penicillius) growing on calcareous sand bottom. e) Deep meadows of Halophila decipiens surrounding coral reefs in Abrolhos National Park (BA). Image credits: U. Seeliger (a), M. S. Copertino (b), Luciano Candisani (c) and J. C. Creed (d,e).

some scarce meadows dominated by $R$. maritima confined to enclosed lagoons and water bodies, isolated from the sea or temporarily connected to it by narrow channels called igarapés (Lagoa da Jensen in Maranhão, CASTRO et al., 2015; Salina dos Roques in Pará, U. MEHLIG, Per. Com.)

\section{2) The Northeast coast: SEDiment Starved}

The northeastern region of Brazil is a sedimentstarved coastal zone, resulting from low relief, small drainage basins and a semiarid climate (DOMINGUEZ, 2009; MUEHE, 2010). The coast is dominated by sedimentary cliffs (Barreiras group), the river runoff is extremely low and the whole area suffers from coastal erosion. The coastline is characterized by the presence of actively retreating cliffs, beachrocks (cemented upper shoreface sediments) and coral-algal reefs built on top of the beach rocks and abrasion terraces (DOMINGUEZ; BITTENCOURT, 1996). 
The northwestern section of the region is a semi-arid coast (Piauí, Ceará and the west coast of Rio Grande do Norte), very dry and highly impacted by erosion (MUEHE, 2010). Seagrasses are relatively abundant in the region, dominated by $H$. wrightii meadows and restricted to intertidal and shallow subtidal areas along rocky (sandstone) shores and inside estuaries and lagoons.

The eastern section of the northeast coast, from south of Rio Grande do Norte to northern Bahia, has a more humid climate (MUEHE, 2010). It includes a barrier reef coast that stretches intermittently for $3,000 \mathrm{~km}$ (between Pernambuco and Bahia States) and comprises coral and sandstone barrier reefs that act like breakwaters, decreasing the wave energy and limiting sediment re-suspension to the shore. The calm and very clear waters formed in the inner shelf lagoons provide the ideal environmental conditions for the development of seagrasses in dense meadows. Therefore the northeast region holds seagrass hotspots, and plant distribution and abundances are lower northward and southward of this region. The juxtaposition of coral fringing reefs and the shoal complex formed by the Todos-os-Santos Bay (the second largest bay in the country covering approximately 1,200 $\mathrm{km}^{2}$ ), Itaparica Island, Morro de São Paulo, Boipeba and Camamu Bay contain extensive seagrass meadows of Halodule and deeper water populations of $H$. decipiens, few of which are known.

\section{3) The EASTERn COAST: DIP-FED WAVE DOMI- NATED DELTAS}

The eastern coast (in Bahia, Espírito Santo and Rio de Janeiro) receives a considerable volume of sediment as a result of the presence of large rivers draining high-relief, humid areas (DOMINGUEZ, 2009). The presence of the sedimentary cliffs is still dominant but less continuous in the southern part. The region is marked by alternations in dominance between the waves generated by the trade winds and the swell waves generated by cold fronts from the south, and it is highly susceptible to the changes in dominance between tropical and subtropical climaticoceanographic processes (MUEHE, 2010). The coast alternates among regions of equilibrium, accretion and erosion, with more than $30 \%$ of the coastal area suffering from erosion, and accretion occurring mainly on the coastal plains of the river delta (DOMINGUEZ, 2009; MUEHE, 2010).

The presence of seagrasses in this region appears to be a trade-off between depth and turbidity. Because waters are turbid due to wave action and river discharge, seagrass meadows occur sporadically, mainly in the following three situations: 1) as sparse intertidal populations, where beach sand is sufficiently stable on the leeward side of beachrock reefs or on the reefs in rock pools with sandy bottoms; 2) as denser intertidal populations on a smaller rock shore forming embayments or estuaries (e.g., Santa Cruz, ES) or in larger subtidal bays where waters are less turbid (e.g., Victoria Bay); and 3) as intertidal-shallow subtidal populations in lagoons ( $R$. maritima) (Southern Espírito Santo). In this compartment, meadows are found in slightly deeper waters further offshore, between the protective reefs, down to at least $20 \mathrm{~m}$ and between deeper reef pinnacles called chapeirões. The largest coral reef banks in the South Atlantic occur in this region (Abrolhos Bank), but the high sediment suspension nearshore prevents seagrass growth. Rhodoliths and calcareous and rhizophytic macroalgae are associated with meadows. South of the Abrolhos bank, extensive sandy beaches occur with beachrock reefs exposed at low tide.

\section{4) The Southeast COAST: DOUble BARRIER- LAGOON}

This compartment, along the Rio de Janeiro State coast, has an almost east-west alignment to the coastline, being highly exposed to storm waves from the south (MUEHE, 2010). The longshore sediment transport tends to be in equilibrium throughout the year, with the less frequent, high-energy waves (swell) from the south and southwest being compensated for by the more frequent waves from the southeast. Strong wave action on the sandy beaches is not conducive to seagrass colonization. The meadows are restricted to channels, bays and lagoon estuaries (e.g. R. maritima in the urban Marapendi and Rodrigo de Freitas Lagoons; $R$. maritima and $H$. wrightii in the Itajuru Channel, Araruama lagoon) or as smaller populations on a rocky shore forming embayments in the Lakes region (H. wrightii) and within the Guanabara Bay (H. decipiens).

\section{5) The Southeast and South Rocky COAST}

From the Ilha Grande Bay (Rio de Janeiro State) to the Santa Marta Cape (Santa Catarina State), the coast is characterized by the proximity of the coastal mountain range (Serra do Mar), resulting in a submerged landscape with a sequence of high cliffs, innumerous small coves and beaches interconnected by rocky shores (DOMINGUEZ, 2009; MUEHE, 2010). From São Vicente to northern Santa 
Catarina, including the coast of Paraná, the coastline is formed by long beaches and wide coastal plains with wide estuaries, such as at Santos and Cananéia in São Paulo, Paranaguá and Guaratuba in Paraná and São Francisco do Sul in Santa Catarina. From northern Santa Catarina to southern Santa Catarina Island, the coastline becomes irregular with outcrops of the crystalline basement and small coastal plains.

Along this coastal region, the intertidal and shallow rocky shores and reefs are dominated by macroalgal beds, whereas seagrass meadows (mainly Halodule) occur on very shallow sandy bottoms or within coastal lagoons. In São Paulo, H. wrightii and $H$. decipiens, are observed in patches, with reduced biomass, within bays and channels. In Santa Catarina these environments were not observed in open waters. The occurrence in this area is restricted to shallow coastal lagoons and estuaries, where Ruppia and more recently Halodule have been listed.

\section{6) The Southern COAST: SANDY MULTIPLE BAR- RIER}

From Santa Marta Cape (Santa Catarina) to Chuí (Rio Grande do Sul) on the border between Brazil and Uruguay, the coastline is formed by a long, wide, fine-grained and continuous beach in front of a multiple barrier-lagoon system, the widest lagoons being the Patos and Mirim Lagoons (MUEHE, 2010). The series of barriers are separated by low-lying areas occupied by freshwater wetlands and large fresh-water bodies, with no access to the sea but for the Rio Grande, Tramandaí and Chuy inlets (TOMAZELLI et al., 2000). This is the longest barrier system in South America and certainly one of the longest in the world (DILLENBURG et al., 2009). The sediment supply to build this large coastal plain came from La Plata River (the second largest river system in South America) with the contribution of local rivers (Camaquã and Jacuí) (DOMINGUEZ, 2009). The direct exposure to the oceanic swell and the high frequency of storm-generated waves submit the shoreline to a harsh wave climate. The coast is a typical wave-dominated coast with a combination of moderate-to-high wave energy and a very low microtidal regime $(0.5 \mathrm{~m})$ (DILLENBURG et al., 2009). The high wave energy and sediment instability together with the high turbidity have prevented the establishment of seagrass meadows at the shore until the present day. However, seagrasses and SAV, dominated by mixed stands of $R$. maritima, oligohaline plants (Zannichellia palustris, Potamogeton striatus) and green macroalgae dominate the coastal lagoons and estuaries (e.g., Patos Lagoon, the Tramandaí-Armazém Complex, Lagoa do Peixe). Ephemeral meadows can occur over great extensions in these very shallow waters (from a few $\mathrm{cm}$ up to $3 \mathrm{~m}$ depth), mainly in summer periods.

THE SITES STUDIED: THE KNOWLEDGE OF SEAGRASSES IN EACH COASTAL REGION

\section{NORTHEAST}

The most representative and dense seagrass meadows in Brazil are concentrated on the northeast coast (OLIVEIRA et al., 1983; MAGALHÃES et al., 1997; MAGALHÃES et al., 2003; FRANÇA et al., 2013) mainly in the Timonha-Ubatuba Estuarine System (PI), at Camocim, Acaraú, Icapuí (CE), Tamandaré, Itamaracá (PE), on the Abrolhos Bank and Morro de São Paulo (BA) (MAGALHÃES; ESKINAZI-LEÇA, 2000; MAGALHÃES; ALVES, 2002; MAGALHÃES; CAZUZA, 2005; BARROS ET AL,. 2014). Two estuarine complexes of extreme biological importance are located on the border of Ceará and Piauí (BARROS,; COSTA; ROCHA-BARREIRA, 2015). In addition to being home to established endangered species such as the manatee, they are breakpoints and feeding grounds for migratory birds. The areas include the largest remaining mangrove forest in northeastern Brazil (except for that in Maranhão state) with an area of more than 10000 hectares. The TimonhaUbatuba Estuarine System, located between the states of Piauí and Ceará, holds the most diverse seagrass meadow found anywhere on the Brazilian coast, where the species Halodule sp., H. wrightii, H. baillonis and $H$. decipiens (BARROS et al., 2014) occur together.

Fishing is the main economic activity of many coastal communities in northeastern Brazil (IDEMA, 1999; IBAMA, 2006), including fisheries for organisms such as lobsters and shrimps with life cycles related to the seagrasses. There are reports of the economic dependence of fishermen in areas with high fishing production where dense areas of seagrass meadows are found -according to the records in Ceará State (IDEMA, 1999) and also in the Santa Cruz Channel and on Itamaracá Island (Pernambuco State) where 5000 fishermen depend on the fisheries (LIMA; QUINAMO, 2000). Coral fishing, the main sea fishing activity in the northeast region (PAIVA; NOMURA, 1965), is still frequently found in the meadows of $H$. wrightii in the intertidal zone, and is practised especially by subsistence fishermen or small-scale producers. 
Goiabeiras Beach (Ceará State). In the semi-arid sector of the Northeast, seagrass meadows are well estabilished on beach rocks. On Goiabeiras Beach, the H. wrightil meadow has a variable shape of approximately $30 \mathrm{~m}$ in length (BARROS; ROCHA-BARREIRA, 2014) with an associated macrofauna comprising 29 crustacean species, 27 molluscan species and 16 families of polychaetes in addition to the ectoprocts and hydrozoans attached to the leaves and cerianthids, nemerteans, oligochaetes and ophiuroids, with amphipods being most abundant aboveground and polychaetes belowground (BARROS, 2008; BARROS; ROCHA-BARREIRA, 2010; 2013). The associated macrofauna, both aboveground (shoots) and $10 \mathrm{~cm}$ into the sediment, is strongly influenced by the local hydrodynamics. The species do not have a distinct vertical distribution because some species are found both aboveground and belowground (BARROS; ROCHABARREIRA, 2010; BARROS; ROCHA-BARREIRA, 2013).

In addition to the features of the substrate on which the seagrass meadow has become established (i.e., rocky and sandy habitats), which strongly influence the biology of the meadows and associated flora and fauna (BARROS et al., 2013), the pronounced seasonality of rainfall and the wind patterns in this region have been related to the variation in the vegetative characters of $H$. wrightii, for which patterns should be monitored for future evaluations related to the influence of climate changes on the meadows of this region (BARROS; ROCHA-BARREIRA; MAGALHÃES, 2013; BARROS; ROCHA-BARREIRA, 2014).

$H$. wrightii meadows have a higher homogeneity in cover percentage and greater canopy height and biomass during the rainy season, probably due to the increase in fine and organic matter percentages in the sediment (BARROS; ROCHA-BARREIRA, 2013; BARROS; ROCHA-BARREIRA, 2014). During the dry season, the meadows are reduced to smaller patches, and some leaves are burnt. The waves, influenced by the increase in wind velocity, remove fine sand and provide an input of medium-coarse sand into the meadows as well as dislodging mature leaves. Despite this, the shoot density in the patches increases during the dry season, promoting retention and increase in diversity of flora and fauna in the meadows (BARROS; ROCHA-BARREIRA, 2013; BARROS et al., 2013).

Barrier Reef Coast (Pernambuco and Alagoas State). The eastern sector of the Northeast has the most representative and abundant seagrass meadows in Brazil
(MAGALHÃES et al., 1997; MAGALHÃES et al., 2003). The region possesses one of the largest marine protected area in Brazil (400,000 ha), APA "Costa dos Corais", a polygon that stretches across $120 \mathrm{~km}$ of the coastal zone (and $30 \mathrm{~km}$ offshore), covers parts of the states of Pernambuco and Alagoas (ICMBio, 2012). The area was created to protect the unique and interconnected coral reefs, seagrass meadows and mangrove systems, with their endemic and endangered species (e.g., the manatee Trichechus manatus).

Seagrass meadows have been recorded at at least 20 sites along the coast of Pernambuco, which includes beaches, coastal lagoons, and estuaries (MAGALHÃES; CAZUZA, 2005) and on the oceanic island, Fernando de Noronha (CREED, 2003). Along the coast of Paraíba, Pernambuco and Alagoas, $H$. wrightii meadows are found from the intertidal zone to a depth of $10 \mathrm{~m}$ and are established mainly in areas protected by beach rocks or coral reefs on both soft and hard substrates (KEMPF, 1970; LABORELDEGUEN, 1963; FRANÇA et al., 2014). H. decipiens is generally found in association with $H$. wrightii, but in calm and protected areas with muddy sediment between $30 \mathrm{~cm}$ and $40 \mathrm{~m}$ depth (KEMPF, 1970; LABOREL-DEGUEN, 1963). H. baillonis occurs together with $H$. wrightii and $H$. decipiens in areas protected by reefs with strong turbidity and up to 3 $m$ depth (MAGALHÃES et al., 2015). R. maritima meadows are found in estuarine areas, of which the Olho d'Água Lagoon in Recife, Pernambuco, where the sediment is muddy and has a high percentage of organic matter, is a good example (COELHO, 1965; MAGALHÃES; CAZUZA, 2004).

A rich fauna comprising mollusks and crustaceans is associated with $H$. wrightii, including especially amphipods, gastropods, isopods and decapods in addition to sea cucumbers and chordates (ALVES, 2000; MAGALHÃES; ALVES, 2002). The meadows are frequently used as nurseries by the peneids Farfantepenaeus brasiliensis and F. subtilis, for which greater abundance occurs during the rainy season and within the meadow area relative to adjacent non-vegetated areas (F. VIANA, pers. comm.). At Tamandaré Beach, Pernambuco, the meadows are established on calcareous sediment derived from fragments of Halimeda sp. and corals. These meadows have a well-defined seasonality, with significantly greater biomass and density during the dry season (SHORT et al., 2006). 
Abrolhos Bank. The Abrolhos Bank is situated in the south of the Bahia state, on a widening (to approximately $200 \mathrm{~km}$ ) of the Brazilian continental shelf that occurs in the southwest Atlantic Ocean between 17 and $20^{\circ} \mathrm{S}$. The tropical region is mainly influenced by the Brazilian Current; it is responsible for the high temperatures of the surface seawater and contains the largest mesophotic reefs in the southern Atlantic as well as rhodolith beds and unconsolidated sediments (LEÃO et al., 2013). The Abrolhos Archipelago, which comprises five small islands with small fringing reefs, is located $65 \mathrm{~km}$ off the southern coast of Bahia state, Brazil, and is part of a marine protected area, the Abrolhos Marine National Park (LEÃO; KIKUCHI, 2001). The shallow, soft-bottomed marine communities near the coral reefs of the Abrolhos archipelago are dominated by macrophytes comprising algae and the seagrasses Halodule wrightii and Halophila decipiens (CREED; AMADO, 1999; DE PAULA et al., 2003).

Despite the considerable research interest invested in the Abrolhos Marine National Park, seagrasses have been overlooked and were not reported until the year 2000 (CREED; AMADO, 1999). Monitoring only began in 2002 using the SeagrassNet Global Seagrass Monitoring Program Protocol (SHORT et al., 2005), and it showed that, in fact, $H$. wrightii and especially $H$. decipiens were probably more common than previously believed. $H$. wrightii is found in shallow sandy areas interspersed with coastal reefs and around the Abrolhos Archipelago while $H$. decipiens is found at a depth of at least $22 \mathrm{~m}$. The suspicion that $H$. decipiens might be very abundant on the Abrolhos Bank was confirmed during a Rapid Assessment Protocol of biodiversity conducted in the region (DUTRA et al., 2006). Of the 45 reef edge/soft-bottom sites selected, Halophila was present at $18(40 \%)$ of them. Although no total area quantification was made, these sites were distributed over a study area of approximately $6,000 \mathrm{~km}^{2}$; thus, the potential importance of $H$. decipiens in the region, especially in terms of primary productivity, could be enormous. Large vertebrates, such as sea chub, parrotfish, surgeonfish (FERREIRA; GONÇALVES, 2006) and green turtles graze intensively on the seagrass and 56 associated seaweed species. Between 5\% and 12\% of the stomach content of herbivourous fishes (Kyphosus spp. 12\%, Acanthurus chirurgus $8 \%$, Sparisoma and Scarus 0.5-5\%) are composed of seagrasses (FERREIRA; GONÇALVES, 2006). Chelonia mydas has been observed grazing on $H$. wrightii meadows, taking 32 bites per minute (J.C. CREED, unpublished data)

\section{SOUTHEAST}

Seagrass beds occur sporadically throughout the states of Espirito Santo, Rio de Janeiro and São Paulo where suitable conditions for seagrass development: shallow unconsolidated substrate, wave-protected position and suitable water quality, are available. Seagrasses are therefore limited to embayments, the leeward side of islands and some estuaries and lagoons. While many studies have been published on the seagrass biology and ecology of the Rio de Janeiro coast (see MARQUES; CREED, 2008 for a review), almost nothing is known about seagrasses in Espirito Santo and São Paulo States other than some distributional observations (OLIVEIRA et al., 1983). Despite the observed decreased biomass and densities (J.C. CREED, unpublished data), there is no published systematic characterization of the community structure or population dynamic of the seagrass beds in these coastal regions. In 2013, as part of an ongoing National Seagrass Mapping Project, 80 sites in Espírito Santo State were visited, and seagrasses were found at 14 points (J.C. CREED, unpublished data). Similarly, on the better known northern coast of Rio de Janeiro, 9 sites visited yielded 6 new recordings (J.C. CREED unpublished data). In São Paulo, seagrasses were registered at about 12 sites (most shallow beaches) during the 80s (OLIVEIRA et al., 1983). The sites were revisited in 2014 and meadows were found in only three of them (P. HORTA, unpublished data). In addition, new subtidal meadows have been recorded (D. GORMAN, unpublished data).

Araruama Lagoon (Rio de Janeiro State). The H. wrightii beds in Rio de Janeiro that were listed by OLIVEIRA et al. in 1983 were revisited ten years later, and $16 \%$ of the seagrass beds were found to have been lost (CREED, 2003). In contrast, according to CREED (2000a), a search for seagrass meadows in the state yielded 12 (of 28) as previously unreported. The authors conclude from these observations that 1) little is known about seagrasses in Rio de Janeiro and 2) we are losing some of what we have. To redress this situation, the Universidade do Estado do Rio de Janeiro (UERJ) initiated a seagrass monitoring program at Araruama Lagoon in Cabo Frio. Monitoring has been conducted seasonally (January, April, July and October) from spring 1995 to the present, following protocols including the SeagrassNet Global Seagrass Monitoring Program (SHORT et al., 2005). The monitoring site is situated on the Ilha do Japonês $\left(22^{\circ} 52.951^{\prime} \mathrm{S}\right.$; $\left.42^{\circ} 00.168^{\prime} \mathrm{W}\right)$ in the Itajuru channel which links the Araruama Lagoon to the sea. The lagoon 
is hypersaline, with salinity varying from 35 to 40 and temperature from 17 to $32.5^{\circ} \mathrm{C}$. The lowest spring tides occur during the day from April to October, and the tidal range is $1.4 \mathrm{~m}$. The area is subject to a bi-directional tidal flow in and out of the lagoon and is protected from wind and waves (CREED, 1997; CREED, 1999). These site features create a unique oceanographic settling. Seagrass meadows comprising $H$. wrightii and some $R$. maritima extend from the intertidal to shallow subtidal zone. Aspects of the short-term temporal dynamics and morphology of the seagrass bed have already been described by CREED (1997, 1999). In addition to the seagrasses, macroalgae, mainly Jania adhaerens J.V. Lamour., Hypnea spp. and Acanthophora spicifera (Vahl) Børgesen, are abundant. The cerith Cerithium atratum (BORN, 1778) is the most highly abundant (mean density $1887 . \mathrm{m}^{-2}$ ) and ecologically important gastropod within the seagrass meadow (CREED, 2000b). Fish, shrimp and blue crab from the seagrass beds are commercially exploited. Over the tenyear period, the average seagrass canopy height showed a consistent decline followed by a recovery. The shoot density was more dynamic (MARQUES et al., 2015). These data show that the dynamics of seagrass change at Cabo Frio are complex and apparently contain multiple cyclic influences. This type of data will be extremely useful in ongoing investigations assessing climate change and its effect on seagrasses in Brazil.

\section{South}

Paranaguá Bay (Parana State). Halodule wrightii meadows occur on shallow subtidal sandy bottoms in the euhaline high-energy sector of Paranaguá Bay, a wellpreserved subtropical estuarine system in southern Brazil. Near their southernmost limit in the South Atlantic, local populations are patchy, unstable and infrequently sexually reproductive. SORDO et al. (2011) assessed the seasonal morphological and biomass variations of a local $H$. wrightii meadow on Rasa da Cotinga Island from a healthy state to its subsequent decline and die-off. The leaf width and length, the number of leaves per shoot, leaf sheath length, rhizome width, internodal length and biomass, together with sediment grain size and $\mathrm{CaCO}_{3}$ and POM contents were measured on six occasions between November 2004 and October 2005. Compared with other Halodule meadows along the Atlantic coast, local plants had shorter and narrower leaves, shorter leaf sheaths, thinner rhizomes, a lower number of leaves per shoot, and higher internodal distances. The highest values for all plant variables were found in the summer. There was an important decrease in shoot density and in below- and above-ground biomass, with the clearance of the internal areas of the meadow, in colder months (June 2005). This started a marked decline in the extent and biomass of the local meadow, which had totally disappeared by the beginning of 2006. It has been suggested that such marked temporal variations in morphology and plant biomass, which may lead to local meadow regression and disappearance, are a latitudinal pattern to be expected. The dynamic appearance and disappearance of seagrass meadows in Paranaguá Bay, which seem to follow a regular and somewhat predictable pattern, are related to the fact that this species is locally close to its southernmost distribution limit. Because of its great adaptability as a pioneer and short-lived species, $H$. wrightii can grow and reproduce vegetatively under stressful conditions such as high turbidity and lower salinities and temperatures. This study also suggests that the increase in spatial differences in plant cover and abundance in a seagrass meadow is an early indicator of future regressions and can be used in monitoring evaluation and/or stress identification programs. The seagrass meadows in Paranaguá Bay have been studied since 2004 (SORDO, 2008), and the steady decline of at least two seagrass meadows has been observed at Rasa da Cotinga Island, accompanying a worldwide trend. The first meadow $\left(25^{\circ} 32^{\prime} 31.8^{\prime}\right.$ ' S; $\left.48^{\circ} 24^{\prime} 04.3^{\prime \prime} \mathrm{W}\right)$ was found in 2004, and had completely disappeared by the beginning of 2006. This decline was attributed to a number of overlapping stress factors, such as low temperatures and higher turbidity levels associated with cold fronts (SORDO et al., 2011). Two months later a new meadow $\left(25^{\circ} 31^{\prime} 51.6\right.$ ' $\mathrm{S} ; 48^{\circ} 23$ ' $47.5^{\prime}$ 'W) appeared in the same area. To identify reliable and consistent proxies of the early stages of seagrass decline for conservation purposes, SORDO and LANA (unpublished data) compared the benthic fluxes in the sediment and water column and the responses of plant and macrobenthic variables as between the two meadows from December 2006 until the complete regression of the Rasa da Cotinga meadow by the beginning of 2008 following an overgrowth of the epiphytic brown algae Hincksia mitchelliae (Harvey) P. C. SILVA. The differences between sites increased with the progressive degradation of the Rasa da Cotinga meadow. With an unexpected boost of epiphytic biomass, plant growth was suppressed and the numbers of burrowing and opportunistic macrobenthic species increased. In the healthy meadow, seagrass 
biomass and the number of leaves followed the usual seasonal trends, and macrobenthic abundance and species richness remained stable with no evident changes in species composition. The nutrient fluxes at the sedimentwater interface were highly inconsistent between and within sites and sampling periods and did not reflect the evident changes in plant and animal variables. The algal overgrowth, together with an increase in the abundance of annelid and crustacean bioturbators only affected oxygen production positively in the advanced stages of seagrass decline. This study showed that plants and animals, rather than the benthic fluxes or nutrient concentrations at the sediment-water interface, were the first and most reliable indicators of the early stages of seagrass decline. Changes in the number of leaves per shoot, abundance and composition of the macrofaunal associations and the host-epiphyte surface interactions could be monitored to detect such changes in regression events. The use of these early warning bioindicators may contribute to more effective management measures for the monitoring and conservation of seagrass ecosystems.

To characterize the type of epiphytism occurring between $H$. mitchelliae and its host plant, PAPINI et al. (2011) compared two samples at the beginning and end of the algal overgrowth by means of electron and optical microscopes. The presence of plasmodesmata between the cells of $H$. mitchelliae only in the late stage of the hostepiphyte interaction indicated a change in the vegetative organization of the algae in relation to its host to improve nutrient absorption and distribution through the epiphyte cells. H. mitchelliae and other epiphytes adhered to the surface of Halodule causing shadowing and the disruption of the osmoregulatory system of the plant. The authors concluded that in the late stage of epiphytism, algal epiphytes led to the death of the seagrasses. The surface interaction between the epiphyte and its host plant may be considered an indicator of seagrass health and could be integrated into monitoring programs for the management of seagrass ecosystems (PAPINI et al., 2011).

Patos Lagoon Estuary (Rio Grande do Sul State). On the extreme southern Brazilian coast, seagrasses live under such extreme and variable environmental conditions that they present the lowest diversity and sparsest distribution on the southeastern Atlantic Coast. With a coastline dominated by exposed sandy beaches and high wave energy, SAV (composed by $R$. maritima, oligohaline, fresh-water grasses and eurihaline macroalgae) in Rio Grande do Sul State is restricted to enclosed estuaries and coastal lagoons (e.g. Tramandaí-Armazém Estuarine Complex, Lagoa do Peixe and Patos Lagoon Estuary.

The largest is Patos Lagoon, the most extensive choked lagoon in the world (KJERFVE, 1986). The system has a high ecological significance and sustains several socialeconomical activities (fisheries, agriculture, aquiculture, port and tourism) (ODEBRECHT et al., 2010).

Nearly $175 \mathrm{~km}^{2}$ of shallow estuarine areas $(70 \%$ of the Patos Lagoon estuary) provides suitable conditions for the settlement and development of SAV, composed mainly $R$. maritima meadows (COSTA et al., 1997; SEELIGER et al., 1997a). These vegetated areas are used as nurseries and habitats by important marine and estuarine fishing resources such as pink shrimp (Farfantepenaeus paulensis), blue crab (Callinectes sapidus), mullet (Mugil platensis), bluefish, catfish and whitemouth croaker (Micropogonias furnieri) (D'INCAO, 1991; GARCIA et al., 1996; GARCIA; VIEIRA, 1997; ASMUS, 1989; COSTA et al., 2015; RUAS et al., 2014), which sustain a local economy involving more than 6000 artisanal and 3000 industrial fishermen (REIS, 1992; HAIMOVICI et al., 1997; KALIKOSKI; VASCONCELOS, 2012). A recent study of fisheries management and conservation in Patos Lagoon concluded that the local vegetated shallow bottoms are essential fish habitats that should be preserved as no-take zones (COSTA et al., 2015).

Fluvial discharge and winds are the driving forces behind the Patos Lagoon's hydrology, whereas the influence of the low tide $(\sim 0.4 \mathrm{~m})$ is limited to the estuary mouth (MÖLLER et al., 2010). The average annual salinity is low (10-15 ppt), but salinity is highly variable throughout the year (0-35 ppt) and between years (ODEBRECHT et al., 2010). Therefore, the shoals $(<2.0 \mathrm{~m})$ are temporally covered by $R$. maritima, the most tolerant and eurihaline of seagrass species, Zannichellia palustris (oligohaline) and drift macroalgal species (mainly Ulva clathrata, U. flexuosa, U. intestinalis, Cladophora spp, Rhizoclonium riparium, Polysiphonia subtilissima) (CAFRUNI et al., 1978; SEELIGER et al., 1997b). Ruppia maritima leaves and stems hold significant biomasses of epiphyte algae (FERREIRA; SEELIGER, 1985), together with the unattached green macroalgae (SILVA, 1995).

Spatial and seasonal variability of seagrass abundance and distribution, accounting for water column and sediment parameters, have already been described (COSTA; SEELIGER, 1989; COSTA et al., 1997; SILVA; ASMUS, 2001), and an ecological model of biomass production has been developed as a function of water depth and 
transparency (SILVA; ASMUS, 2001). The development of seagrass meadows in the Patos Lagoon, their variability and the equilibrium among plant and algal populations are highly dependent on hydrodynamics, particularly on the critical initial stages (COPERTINO; SEELIGER, 2010). When water and sediment movements are moderate (usually in late spring and throughout the summer), light, temperature and salinity enhance the growth rates, biomass allocation and flower production $(\mathrm{KOCH}$; SEELIGER, 1988; COSTA; SEELIGER, 1989; SILVA; ASMUS, 2001; COLARES; SEELIGER, 2006). Due to this synergistic effect, seagrass growth is concentrated in the spring and summer with meadows decaying or disappearing in the winter. Although a high spatial and temporal variability is intrinsic to the local populations, drastic reductions in abundance ( 3 times lower biomass compared with the values found in the 1980s and 1990s) and distribution (more than 50\%) were observed between the end of the 1990s and the beginning of the 2000s, causing extreme habitat fragmentation and changes in community structure (COPERTINO, 2010; COPERTINO; SEELIGER, 2010; ODEBRECHT et al., 2010). The changes, including sudden disappearance from more exposed areas, were strongly correlated with precipitation anomalies and extreme events (storms and wind generated waves), some of them associated with ENSO episodes. Within these periods (e.g., 1997/1998, 2001/2003), precipitation anomalies occurred in southern Brazil and were reflected in increases in the Patos Lagoon's fluvial discharge (MÖLLER et al., 2009). The higher discharge and anomalous flows increased the average estuarine water level and turbidity, reduced salinity and enhanced sediment movement in the shallow areas. A single extreme event (October 2001) driven by a synergistic effect of high fluvial discharge and prevailing strong winds quickly raised the estuarine water level, dislodging salt marsh areas and several seagrass meadows. The responses of the $R$. maritima population to the unfavorable conditions were relatively rapid, but complete recovery was a slow process ( $\sim 10$ years in some areas). A reduction in seed bank and germination rates appeared to reduce the chances of the formation of meadows (CORDAZZO, 2004). As a result of habitat fragmentation, the few shoots or seedlings were highly vulnerable to even moderate water and sediment movement, thus inhibiting meadow formation.

\section{THE CONSERVATION STATUS AND MAIN THREATS}

Seagrasses and submerged aquatic vegetation (SAV) have been suffering major changes and losses in abundance, community structure and functions for the last 40 years, most notably from the worldwide deterioration of water quality (ORTH et al., 2006; BURKHOLDER et al., 2007; WAYCOTT et al., 2009). The causes of the rapid seagrass decline during the last decades of the last century are mainly attributed to the increasing impacts associated with anthropogenic activities such as the occupation of the coastal zone, eutrophication, overfishing, dredging and pollution (SILBERSTEIN et al., 1986; SHEPHERD et al., 1989; PERGENT-MARTINI; PERGENT, 1996; BURKHOLDER et al., 2007). On the other hand, fast and significant losses have also been linked to extreme natural events such as coastal erosion, abnormally high temperatures, storms, cyclones, precipitation extremes, drought and desiccation (PREEN et al., 1995; SHORT; WYLLIE-ECHEVERIA, 1996; SEDDON et al., 2000; SEDDON; CHESHIRE, 2001), many of which are predicted to increase in frequency and intensity in several coastal areas in response to global climate change (TRENBERTH et al., 2007; BINDOFF et al., 2007). Furthermore, the observed and predicted changes in water $\mathrm{CO}_{2}$ concentrations, temperature and sea level may potentially affect the physiology, abundance and structure of seagrass communities (DUARTE, 2002). All of these factors together, i.e., environmental degradation and global climate changes, will certainly impact the structure and functioning of these submerged vegetated habitats.

ANTHROPOGENIC IMPACTS ALONG THE BRAZILIAN COAST: A HISTORICAL PERSPECTIVE

In general, the gradual and slow worldwide decline of seagrass meadows has been attributed to anthropogenic impacts such as eutrophication, runoff of nutrients and sediments, aquaculture, destructive fishing practices and pollution (SBERSTEIN et al., 1986; SHEPHERD et al., 1989; PERGENT-MARTINI; PERGENT, 1996; BURKHOLDER et al., 2007; BJÖRK et al., 2008). With an average population density of 22 inhabitants $/ \mathrm{km}^{2}$, the level of anthropization in Brazil is less evident than it is in European and American countries; however, it is highly concentrated in metropolitan coastal areas.

As a consequence of historical processes, Brazilian coastal areas have been substantially altered over recent centuries (DIAS et al., 2012). Since the arrival of the first Europeans, human populations have been established mostly in estuarine areas (e.g., Salvador, Rio de Janeiro, Santos, Iguape, Paranaguá, and Porto Alegre). The settlement of the Portuguese Royalty in Brazil (1808), 
together with Independence (1822), promoted an increase in the size and activity of harbors (expansion, dredging, inlet fixation, breakwaters, jetties) and urban growth along the shores, and the former city-ports became large cities. From 1940 on, mining activities (iron and steel industries) along with other industrial activities demanded significant changes in the major ports of Santos (SP), Rio de Janeiro (RJ), Paranaguá (PR) and Vitória (ES). Consequently, pollution became a problem within areas such as Guanabara Bay (RJ) and the estuaries of Sao Paulo state (BAPTISTA NETO et al., 2013). Since the middle of the 20th century, a tourist boom has also been affecting the Brazilian coast. Multiple resorts have been constructed, promoting urban development in cities such as Fortaleza (PAULA et al., 2013), Recife (COSTA et al., 2008), Balneário Camboriú (COSTA et al., 2006), and Santos (MELLO, 2008), among others. As a result of all of these anthropogenic impacts, the Brazilian coast has been suffering from erosion, land reclamation and pollution problems, and the degree of deterioration has been increasing still further in recent years (GALVÃO; NOLASCO, 2013; SOUSA et al., 2013).

Within this context, historical and published records of seagrass losses across Brazil are scarce. By comparing historical observations and studies (of the 1970s and 1980s) with recent monitoring and experimental studies (of the 1990s and 2000s), major seagrass changes and losses (up to $50 \%$ losses) have been detected, mainly surrounding metropolitan areas such as Recife (SHORT et al., 2006; MAGALHÃES; ALVES, 2002; PITANGA, 2012), Rio de Janeiro, Búzios, Cabo Frio (CREED, 2000a; CREED, 2003), Santos Bay (E. C. OLIVEIRA, Pers. Comm.) and Patos Lagoon Estuary (COPERTINO, 2010; COPERTINO; SEELIGER, 2010; ODEBRECHT et al., 2010). The effects of anthropogenic impacts on each coastal region may interact with regional features such as wind regime, hydrology and oceanographic and coastal morphology. Brazilian seagrass meadows have thus been exposed to different anthropogenic impacts of varying intensity, and they may be vulnerable to different stresses according to climate and coastal dynamics and ecosystem resiliencies.

In the northeast region, anthropogenic and natural impacts on seagrasses have been qualified and quantified along the Pernambuco coast, indicating significant changes in the meadows' extension and abundances (PITANGA et al., 2012). The losses have been attributed to impacts such as continental discharge, urban development, boating activity, destructive fishing techniques and the dumping of solid waste (PITANGA et al., 2012). While some losses have been attributed to natural causes or extreme events (SHORT et al., 2006), many meadows have been reduced due to seagrass harvesting to feed captive manatees (MAGALHÃES; ALVES, 2002). The local media and fishing community have attributed the decline in fishery production to shoal grass (H. wrightii) losses. Similarly, the construction of the coastal breakwaters and artificial structures around Fortaleza (Ceará State) has resulted in high levels of coastal erosion associated with greater exposure to wave energy and ocean storms (PAULA et al., 2013). Seagrass habitats in this coastal region are, therefore, highly vulnerable to increases in wave impacts, sediment erosion and burial. Insights into anthropogenic impacts have also come from the Abrolhos Marine Protected Area. Despite being within a marine protected area, the seagrass meadows in the Abrolhos National Park lose 0.5 percent of their area per year due to anchor damage (CREED; AMADO, 1999). The observed reductions in seagrass density and the changes in the community structure can require more than a year to recover after a single impact.

The southeastern region is probably the most impacted coastal area in Brazil. It has been subjected to successive phases of land disturbance since the sixteenth century as a consequence of widespread urbanization (BAPTISTA NETO et al., 2013a). In common with most of the humid tropics, the Southeast Coastal Range is subject to an extremely erosive climatic regime characterized by periods of prolonged and frequently intense rainfall (BAPTISTA NETO et al., 2013a), which increases continental runoff into the Rio de Janeiro, São Paulo and Espirito Santo coastal regions. The opening of coastal inlets in the Cananéia region (São Paulo) has brought about changes in hydrodynamics, including a decrease in salinity, an increase in turbidity and further changes in geomorphology and sedimentation patterns (MAHIQUES et al., 2009). Several organic geochemical indicators suggest that the changes in sediment organic matter reflect the alteration of the processes of the occupation and urbanization which have been occurring in the areas surrounding metropolitan waters over the last 70 years. These processes have included the conversion of mangrove forests into urban areas, bridge building and the installation of treatment plants (GRILLO et al., 2013; BAPTISTA NETO et al., 2013a). In and surrounding Guanabara Bay, for example, the catchment area has been greatly modified by human activities over the last 100 years, in particular by the deforestation and 
uncontrolled settlemen, which have generally increased the river discharges and sediment loads flowing into the bay (BAPTISTA NETO et al., 2013b). Consequently, the average rates of sedimentation are very high (from 0.67 $\mathrm{cm} \mathrm{y}^{-1}$ to $2 \mathrm{~cm} \mathrm{y}^{-1}$ ) compared with other less impacted environments in southeastern Brazil. The concentration of heavy metals has shown a constant increase over the last 50 years, related to an increase in urbanization (post-1950) and deforestation (pre-1950) in the catchment area. The same pattern was also observed for the organic carbon flux, which could indicate the recent impact of the dumping of untreated sewage into the bay. The high levels of estuarine sediment contamination by organic compounds and heavy metals are typical of highly urbanized and industrialized estuaries around the world. Along the São Paulo coast, the spread and low density of seagrass meadows in the shallow subtidal zone, exposed to a high variability in water turbidity, have decreased during the last several decades (E. OLIVEIRA, Pers. Com.). The H. wrightii beds listed by OLIVEIRA et al. (1983) were revisited ten years later and $16 \%$ of them were found to have been lost (CREED, 2003).

In the extreme southern region of Brazil, a long-term study of the Patos Lagoon Estuary has proved fundamental to the understanding of the complexity of and environmental responses to natural and anthropogenic impacts (SEELIGER; ODEBECHT, 2010; ODEBRECHT et al., 2010). Human impacts such as the construction of jetties, the dredging of navigation channels, sediment removal and resuspension and the input of domestic and industrial effluents, have led to profound changes in the ecology of the Patos Lagoon Estuary. Among them, seagrass coverage and abundance have been reduced by more than $50 \%$ since the 80 s (COPERTINO, 2010; COPERTINO; SEELIGER, 2010). The expansion of aquatic plant species with low tolerance to high salinity (COSTA et al., 2003; MARANGONI; COSTA, 2009) and the marked reduction of the area and abundance of seagrass meadows (COPERTINO; SEELIGER, 2010) cannot be explained solely by changes in hydrology. Increases in frequency and abundance of opportunistic macroalgae and the formation of large green tides have been registered (GIANASI et al., 2011; LANARI; COPERTINO, under review) at the same time that eutrophication processes have been detected (ABREU et al., 2006).

\section{Climate Variability and Global Climate CHAnge}

Climate change is predicted to profoundly impact marine biodiversity and ecosystems by changing the functioning, behavior, and productivity of organisms, leading to shifts in the size, structure, spatial range, and seasonal abundance of populations (DONEY et al., 2012). The first studies on the effects of climate changes on seagrasses and SAV were comprehensive reviews, extrapolating information from physiological and ecological studies to assess the potential impacts of global climate change on seagrasses (SHORT; NECKLES, 1999; DUARTE, 2002). Of more than 1,400 articles found on seagrasses and SAV, only $416(\sim 3 \%)$ are related to climate change factors and issues (Web of Knowledge, March 6, 2015). A growing number of studies attribute the worldwide changes in seagrasses to climate variability and global climate change (UNSWORTH, 2014), although most have only mentioned or contextualized climate change problems in their introductions and final discussion. Many studies are observational, with climate change effects being extrapolated from mid-long term temporal series or from the plant/meadow responses to extreme events such as hotter summers, hurricanes, anomalous runoff, droughts and so on (e.g., CARLSON et al., 2010). During the last decade, few studies have tested working hypotheses or investigated particular climate change effects through design experiments (e.g., UNSWORTH et al., 2012; COLLIER; WAYCOTT, 2014; GARTHWIN et al., 2014; YAAKUB et al., 2014) or produced prognoses based upon IPCC climate scenarios and modelling (SAUNDERS et al., 2014).

The expected impacts of climate change on oceans and coastal areas that will potentially affect seagrasses and other submerged aquatic vegetation are manifold (Table 1). For instance, it is expected that the increasing rate of global climate change with the associated increases in temperature and carbon dioxide will impact the redistribution of current seagrass habitats. Differences between species in their ability to compete for $\mathrm{CO}_{2}$ could lead to enhanced competition between algae and seagrasses, shifting the species distribution (SHORT; NECKLES, 1999). Nonetheless, few authors have provided empirical evidence linking the observed changes in seagrass populations to climate change with a reasonable level of confidence. Firstly, the lack of continuous data series makes it impossible to find indications of long-term changes in abiotic and biological parameters. Even for the few long-term series, it is hard to separate the evidence of the changes in global climate (such as temperature increase) on the regional and local scales due to high natural variability and, particularly, the impacts of other anthropogenic activities. 
Table 1. Predicted climate change impacts and their hypothetical effects on seagrass and SAV meadows and associated species.

\begin{tabular}{ll}
\hline Impact & \multicolumn{1}{c}{ Effects on seagrass meadows } \\
\hline Warming (air and sea surface temperature) & Changes in species geographic distribution and reproduction timing \\
\hline Increases in Nutrient Load & $\begin{array}{l}\text { Increases in the abundance of epiphyte algae and opportunistic macroalgae; changes in species } \\
\text { composition; appearance of toxic algae }\end{array}$ \\
\hline Sea level rise/increases in wave energy & Changes in lower and upper limits (meadow range); reductions in abundances \\
\hline Changes in salinity & Physiological stress; changes in leaf and shoot morphology \\
\hline Increases in turbidity & Reduction in primary production and meadow abundance \\
\hline Increases in $p \mathrm{CO}_{2} /$ Acidification & $\begin{array}{l}\text { Changes in photossyntetic response/reduction in calcification rates of associated calcareous } \\
\text { macroalgae and shellfish }\end{array}$ \\
\hline Extremes events (floods, storm surge) & Meadow burial, fragmentation and disappearance \\
\hline
\end{tabular}

In Brazil, losses on the Tamandaré Beach (Pernambuco) have been related to the increasing frequency and intensity of storms in 2003, which increased the transport of sediments, acting on the distribution and biomass of $H$. wrightii (SHORT et al., 2006). On the semiarid coast, the intertidal seagrass meadows are strongly influenced by rain and wind patterns, and, consequently, they may be drastically affected by the effects of climate change related to the diminishing of precipitation indexes (REBOUÇAS, 2004) and the doubling of the actual windy velocity (PEREIRA et al., 2013), expected by the end of this century.

Ecological assessments at the biogeographical limits of distribution may also provide important insights for predicting shifts in seagrass range in response to climate change and ocean acidification. During the 80s, the southernmost $H$. wrightii meadows were recorded at $23^{\circ}$ $55^{\prime}$ S, around Santos (São Paulo State). In the late early $2000 \mathrm{~s}, H$. wrightii meadows were found at $25^{\circ} 30^{\prime} \mathrm{S}$, in Paranaguá Bay (Paraná State) (SORDO et al., 2011). A recent study on sporadic $H$. wrightii meadows has suggested that, at its southernmost distribution limit, their survival depends on their degree of exposure (SORDO; LANA, unpublished data). In protected and preserved areas the plant communities are stable and could be extending their distribution. In 2012, almost ten years later, a $H$. wrightii prairie was found further south, at $27^{\circ} 35^{\prime} \mathrm{S}$, in Florianópolis (Santa Catarina State), which is permanently epiphytized by the macroalgae Hincksia and Polysiphonia, and disappears cyclically every summer. The events described above, in particularly the recent appearance of the species in Florianópolis, raise the hypothesis that the species may be extending its distribution poleward. Although this shift in the latitudinal limits may be a response to global warming, the projected increases in average sea temperature and $\mathrm{CO}_{2}$ levels may also stimulate the proliferation of opportunistic algal species which outcompete seagrasses for light, space and nutrient resources. Consequently, the survival and widening of the range of $H$. wrightii at its southernmost geographical limit in the southwestern Atlantic may be related not only to the degree of exposure but also to its ability to compete with ephemeral macroalgal species. Despite the registered evidences that the tropical seagrass $H$. wrightii is extending its distribution further south, we still lack a proper ecological assessment along the southwestern Atlantic coast, which could include experimental studies and a species distribution model, in order to better understand the effect of temperature and $\mathrm{CO}_{2}$ increases on the distribution of seagrass species.

In the Patos Lagoon estuary in southern Brazil, the relationship between climatic/hydrological parameters and the distribution and abundance of estuarine SAV have been analyzed for a period of 30 years (COPERTINO, 2010; COPERTINO; SEELIGER, 2010; ODEBREHT et al., 2010). Although they present high seasonal and interannual variability, both seagrasses and macroalgae suffered drastic reductions between the mid-1990s and beginning of this century (1996 to 2004). ENSO episodes, which appear to have increased in frequency during the last several decades, were inversely related to the abundance of SAV by altering precipitation patterns and causing extreme discharges through the estuary. The first significant biomass reduction was observed in 1996, and just before the year 2000, meadows were gradually reduced. In 2002 and 2003, $R$. maritima meadows disappeared completely from most estuarine areas after extreme precipitation and fluvial discharges, with values $\left(\sim 5000 \mathrm{~m}^{-2} \mathrm{~s}^{-1}\right)$ three times larger than the annual means (MÖLLER et al., 2009). The rise in estuarine water levels during this period caused erosion on salt marsh margins, which lost between $40 \%$ and $100 \%$ of their intertidal habitats (MARANGONI, 
2008), transporting high amounts of sediment and plant material to adjacent submersed areas. The tendency of freshwater runoff to increase is thought to be caused by the increased precipitation over southern South America (MÖLLER et al., 2009), which has experiencied a warmer and wetter period during recent decades (GARREAUD et al., 2009); nevertheless, changes in land use (deforestation, urbanization) may also be involved. After El Niño periods, there are drops in river flow and water level, resulting in increases in light availability to benthic primary producers. However, in the absence of seagrasses, the bare bottoms can be fast occupied by opportunistic algae, characterizing phase-shifts to macrolgal dominated states (COPERTINO; SEELIGER, 2010). Dry periods, associated with lower wind stress, promote low water renewal, the maintenance of high algal biomasses and the recycling of organic matter within the shoals, potencially triggering the overgrowth of macroalgae and the formation of green tides (LANARI; COPERTINO, under review). During summer periods, the rapidly growing algae can cover between $70 \%$ and $100 \%$ of shallow areas, with biomass values compared to those found in eutrophicated estuaries (FLINDT et al., 1997; MARTINS; MARQUES, 2002).

Although the seagrass decline occurred relatively fast, the recovery process took more than 10 years, relying on a reduced seed bank, low germination rates and the high dependence on favorable water conditions and sediment stability. High macroalgal biomass interferes with the recovery of the seagrass meadows, by reducing light at the bottom and because of the effects of the toxic compounds released from decay. The fast biomass decay causing anaerobic conditions at the sediment surface, may be responsible for collapses of the benthic infauna (CUMMINGS et al., 2004). The shift from a seagrassdominated to a drift-algae-dominated state may impose ecological consequences such as the reduction of stable habitats for invertebrates and fishes, some of which are important local fishing resources.

The above studies and results can have important implications for the prediction of the impacts of climate change on the coastal ecosystem and seagrass habitats of Brazil. Climate change projections over South America show an increase in wet-season precipitation and a decrease in dry-season precipitation over most of the continent (MARENGO et al., 2009; KOCH et al., 2011). Precipitation intensity is greatest over southern South America in the present-day simulation and in the future, implying increased river flow and an increased risk of flooding in this region (MILLY et al., 2005; KOCH et al., 2011). Southern South America is one of the extratropical regions most affected by the ENSO regime, and southern Brazil is the region with the clearest reflections of El Niño, marked by warmer periods and precipitation anomalies (GRIM et al., 2000). Projections of anthropogenic climate change models indicate an increase in the frequency of ENSO episodes in the near future (TIMMERMAN et al., 1999; FEDOROV; PHILANDER, 2000; YEH et al., 2009). If all of these predicted tendencies are proven correct, the conservation of seagrass habitats and the estuarine ecosystems in Southern Brazil may be at risk. Experimental and modeling studies are still necessary to enable us to draw conclusions about past and future tendencies in the abundance and distribution of seagrasses in the Southwestern Atlantic, including past investigations on a larger spatial scale.

\section{CONCLUSIONS}

The current conservation status of Brazilian seagrasses and SAV is critical. We still rank a decade or two behind the more scientifically developed centers in terms of quantitative information or process-focused research. The unsustainable exploitation and occupation of coastal areas (DIAS et al., 2012) and the manifold anthropogenic footprints left during the last 100 years (TESSLER et al., 2006; MAHIQUES et al., 2009) have led to the loss and degradation of shoreline habitats potentially suitable for seagrass occupation surrounding coral or sand reefs, bays, coastal lagoons and estuarine shoals. Despite this worrisome status and trends of decline, South American seagrass formations are rarely included or cited in global reviews or ecological models.

Knowledge of the prevailing patterns and processes governing seagrass structure and functioning along the $9000 \mathrm{~km}$ Brazilian coast is sorely needed for the global discussion on climate changes. Our review is a first and much needed step toward a more integrated and inclusive approach to the diversity of coastal plant formations along the Southwestern Atlantic coast. It is also a regional alert to the projected or predicted effects of global changes on the goods and services provided by regional seagrasses and SAV.

Future studies must be planned and designed to incorporate spatial and temporal variation into multiscale, nested approaches. Assessing the effects of climate change on regional seagrasses will also require continuous and 
long-term monitoring. The systematic implementation of impact assessment and monitoring protocols will be necessary for a better understanding of the largescale and longterm relative importance of environmental drivers on seagrass resources and services. Such integrated approaches are particularly needed in the regions under higher human pressure and are thus more vulnerable to the projected changes in climate. In addition to the description and quantification of still-unknown meadow areas, experimental approaches (especially in long-term studies) are still much needed in Brazil. By addressing spatial and temporal variations in multiscale approaches and by developing experimental protocols, the Brazilian scientific community will be able to better address the extent and implications of projected changes and the associated fluctuations in carbon stock.

\section{ACKNOWLEDGEMENTS}

The present review was conceived by the group "Submerged Vegetated Bottoms" of the Brazilian Network for Benthic Studies (REBENTOS), sponsored by CNPq (Proc. 563367/2010-5) and FAPESP (Proc. 2010/52323-0). M. O. L., K. V. B. and L. S. were granted $\mathrm{PhD}$ scholarships by, respectively, $\mathrm{CNPq}$, CAPES and the Spanish Agency for International Cooperation for Development. Data and information about Brazilian seagrasses were surveyed and compiled during years or decades by the authors, within individual or integrated projects (e.g. SeagrassNet, Mapping Brazilian Seagrasses, Brazilian Long Term Ecological Research-LTER), students' thesis and dissertations. The data basis on Brazilian seagrasses was created and provided by J. C. C., updated and analised by M. S. C. and M.L. All the authors contributed to the present study by providing regional data, discussing the results, and commenting and editing the manuscript at several stages. We would like to thank B. Gianasi and A. Machado for improving the seagrass distribuition map.

\section{REFERENCES}

ABREU, P. C.; COSTA, C. S. B.; BEMVENUTI, C. E; ODEBRECHT, C.; GRANELLI, W.; ANESIO, A. M. Eutrophication processes and trophic interactions in a shallow estuary: Preliminary results based on stable isotope analysis $\left(\delta^{13} \mathrm{C}\right.$ and $\left.\delta^{15} \mathrm{~N}\right)$. Estuar. Coast., v. 29, n. 2, p. 277-285, 2006.

ALVES, M. S.; ARAÚJO, M. J. G. Moluscos associados ao fital Halodule wrightii Aschers na Ilha de Itamaricá. Trab. Oceang. Univ. Fed. Pernamb., v. 27, p. 91-99, 1999.
ASMUS, M. L. Pradarias de gramíneas marinhas (Ruppia maritima) como áreas vitais na região estuarial da Lagoa dos Patos. In: Anais do III Encontro Brasil Gerenciamento Costeiro. Fortaleza, 1989. p. 291-299.

BAPTISTA NETO, J. A.; BARRETO, C. F.; SILVA, M. A. M.; SMITH, B. J.; MCALLISTER, J. J.; VILELA, C. G. Nearshore sedimentation as a record of landuse change and erosion: Jurujuba Sound, Niterói, SE Brazil. Ocean Coast. Manag., v. 77, p. 31-39, 2013a.

BAPTISTA NETO, J. A.; PEIXOTO, T. C. S.; SMITH, B. J.; MCALLISTER, J. J.; PATCHINEELAM, S. M.; PATCHINEELAM, S. R.; FONSECA, E. M. Geochronology and heavy metal flux to Guanabara Bay, Rio de Janeiro state: a preliminary study. An. Acad. Bras. Ciênc., v. 85, n. 4, p. 1317-1327, 2013b.

BARBIER, E. B.; HACKER, S. D.; KENNEDY, C. J.; KOCH, E. W.; STIER, A. C.; SILLIMAN, B. R. The value of estuarine and coastal ecosystem services. Ecol. Monogr., v. 81, n. 2, p. 169-193, 2001.

BARROS, K. V. S. Efeitos da variação sazonal do ecossistema Halodule wrightii sobre comunidades bentônicas associadas, na praia das Goiabeiras, Fortaleza. Dissertação (Mestrado em Ciências Marinhas Tropicais). Fortaleza, Universidade Federal do Ceará, Fortaleza, 2008. 154 f.

BARROS, K. V. S.; COSTA, F. N.; ROCHA-BARREIRA, C. A. A Halophila baillonis Ascherson bed on the semiarid coast of Brazil. Feddes Repert., v. 125, n. 3/4, p. 103-107, 2014.

BARROS, K. V. S.; ROCHA-BARREIRA, C. A. Caracterização da dinâmica espaço-temporal da macrofauna bentônica em um banco de Halodule wrightii Ascherson (Cymodoceaceae) por meio de estratificação. Rev. Nord. Zool., v. 4, n. 1, p. 73$81,2009 / 2010$.

BARROS, K. V. S.; ROCHA-BARREIRA, C. A. Responses of the molluscan fauna to environmental variations in a Halodule wrightii Ascherson ecosystem from Northeastern Brazil. An. Acad. Bras. Ciênc., v. 85, n. 4, p. 1397-1410, 2013.

BARROS, K. V. S.; ROCHA-BARREIRA, C. A. Influence of environmental factors on a Halodule wrightii Ascherson meadow in Northeastern Brazil. Braz. J. Aquat. Sci. Tech., v. 18 , n. 2, p. 31-41, 2014.

BARROS, K. V. S.; ROCHA-BARREIRA, C. A.; MAGALHÃES, K. M. Ecology of Brazilian seagrasses: is our current knowledge sufficient to make sound decisions about mitigating the effects of climate change? Iheringia Sér. Bot., v. 68, n. 1, p. 155-170, 2013.

BERNER, R. A.; KOTHAVALA, Z. Geocarb III: a revised model of atmospheric $\mathrm{CO} 2$ over phanerozoic time. Am. J. Sci., v. 301, p. 182-204, 2001.

BINDOFF, N. L.; WILLEBRAND, J.; ARTALE, V.; CAZANAVE, A.; GREGORY, J. M.; GULEV, S.; HANAWA, K.; LE QUÉRÉ, C.; LEVITUS, S.; NOJIRI, Y.; SHUM, C. K.; TALLEY, L. D.; UNNIKRISHNAN, A. S. Observations: oceanic climate change and sea level. In: SOLOMON, S.; QIN, D.; MANNING, M.; CHEN, Z.; MARQUIS, M.; AVERYT, K. B.; TIGNOR, M.; MILLER, H. J. (Eds.). Climate change 2007: The physical science basis. Contribution of Working Group I to the Fourth Assessment Report of the Intergovernmental Panel on Climate Change. Cambridge: Cambridge University Press, 2007. p. 385-432. 
BJÖRK, M.; SHORT, F.; MCLEOD, E.; BEER, S. Managing seagrasses for resilience to climate change. Gland: World Conservation Union Global Marine Programme, 2008. 55 p.

BLANDON, A.; ZUERMGASSEN, P. S. E. Quantitative estimate of commercial fish enhancement by seagrass habitat in southern Australia. Estuar. Coast. Shelf Sci., v. 141, p. 1-8, 2014.

BURKHOLDER, J.; LIBRA, B.; WEYER, P.; HEATHCOTE, S.; KOLPIN, D.; THOMER, P. S.; WICHMAN, M. Impacts of waste from concentrated animal feeding operations on water quality. Environ. Health Perspect., v. 115, n. 2, p. 308-312, 2007.

CAFRUNI, A. M. Autoecologia de Ruppia maritima L. no estuário da Lagoa dos Patos. Tese. Rio Grande, Universidade Federal do Rio Grande do Sul, 1983. 65 f.

CAFRUNI, A.; KRIEGER, J. A.; SEELIGER, U. Observações sobre Ruppia maritima L. (Potamogetonaceae) no estuário da Lagoa dos Patos (RS-Brasil). Atlântica, v. 3, p. 85-90, 1978.

CARLSON JÚNIOR, P. R.; YARBRO, L. A. Y.; KAUFMAN, K. A.; MATTSON, R. A. Vulnerability and resilience of seagrasses to hurricane and runoff impacts along Florida's west coast. Hydrobiologia, v. 649, n. 1, p. 39-53, 2010.

CASTRO, A. D. J. V.; COLARES, I. G.; FRANCO, T. C. R. S; CUTRIM, M. V. J.; LUZIVOTTO-SANTOS, R. Using a toxicity test with Ruppia maritima (Linnaeus) to assess the effects of Roundup. Mar. Pollut. Bull., v. 91, n. 2, p. 506-510, 2015.

COELHO, P. A. Estudo ecológico da Lagoa do Olho d'água, Pernambuco, com especial referência aos crustáceos decápodos. Trab. Oceang. Univ. Fed. Pernamb., v. 7/8, p. 5170, 1965.

COLARES, I. G.; SEELIGER, U. Influência da luz sobre o crescimento e a produção de biomassa de Ruppia maritima L. em cultivo experimental. Acta Bot. Bras., v. 20, n. 1, p. 31-36, 2006.

COLLIER. C. J.; WAYCOTT, M. Temperature extremes reduce seagrass growth and induce mortality. Mar. Pollut. Bull., v. 83, n. 2, p. 483-490, 2014

CONNOLLY, R. M. Seagrass. In: POLOCZANSKA, E. S.; HOBDAY, A. J.; RICHARDSON, A. J. (Eds.). Marine Climate Change in Australia: impacts and adaptation responses report card. Southport: NCCARF, 2009. p. 1-14.

COPERTINO, M. S. Patos Lagoon - Climate variability and the state of seagrasses. Seagrass-Watch, v. 40, p. 4-5, 2010.

COPERTINO, M.; SEELIGER, U. Hábitats de Ruppia maritima e de macroalgas. In: SEELIGER, U.; ODEBRECHT, C. (Eds.). O Estuário da Lagoa dos Patos: um século de transformações. Rio Grande: FURG, 2010. p. 92-98.

CORDAZZO, C. V. Produção de sementes e estabelecimento dos fundos de Ruppia matima L. no estuário da Lagoa dos Patos (RS). In: Anais do VI Simpósio de Ecossistemas Brasileiros: patrimônio ameaçado. São Paulo, 2004. p. 291-298.

COSTA, C. S. B.; MARANGONI, J. C.; AZEVEDO, A. M. G. Plant zonation in irregularly flooded salt marshes: relative importance of stress tolerance and biological interactions. J. Ecol., v. 91, n. 6, p. 951-965, 2003.

COSTA, C. S. B.; SEELIGER, U. Vertical distribution and resource allocation of Ruppia. maritima L. in a southern Brazilian estuary. Aquat. Bot., v. 33, n. 1/2, p. 123-129, 1989.
COSTA, C. S. B.; SEELIGER, U.; OLIVEIRA, C. P. L.; MAZO, A. M. M. Distribuição, função e valor de habitat das marismas e pradarias submersas do estuário da Lagoa dos Patos (RS, Brasil). Atlântica, v. 19, p. 67-85, 1997.

COSTA, H. A.; PEREIRA, R. M. F. A.; HOFFMAN, V. E. Compreendendo o espaço turístico de Balneário Camboriú (SC) como Insumo para o Estudo da Competitividade Local. Turismo-Visão e Ação, v. 8, n. 2, p. 223-234, 2006.

COSTA, M. D. P.; POSSINGHAM, H. P.; MUELBERT, J. H. Incorporating early life stages of fishes into estuarine spatial conservation planning. Aquat. Cons. Mar. Fres. Ecos., in press, 2015.

COSTA, M. F.; ARAÚJO, M. C. B.; SILVA-CAVALCANTI, J. S.; SOUZA, S. T. Verticalização da Praia da Boa Viagem (Recife, Pernambuco) e suas Consequências Sócio-Ambientais. Rev. Gest. Cost. Integr., v. 8, n. 2, p. 233-245, 2008.

COSTANZA, R.; D'ARGE, R.; GROOT, R.; FARBER, S.; GRASSO, M.; HANNON, B.; NAEEM, S.; LIMBURG, K.; PARUELO, J.; O’NEILL, R. V.; RASKIN, R.; SUTTON, P.; VAN DEN BELT, M. The value of the world's ecosystem services and natural capital. Nature, v. 287, p. 253-260, 1997.

COSTANZA, R.; GROOT, R.; SUTTON, P.; PLOEG, S. D. V.; ANDERSON, S. J.; KUBISZEWSKI, I.; FARBER, S.; TURNER, R. K. Changes in the global value of ecosystem services. Glob. Environ. Chang., v. 26, p. 152-158, 2014.

CREED, J. C. Morphological variation in the seagrass Halodule wrightii near its southern distributional limit. Aquat. Bot., v. 59, n. 1/2, p. 163-172, 1997.

CREED, J. C. Distribution, seasonal abundance and shoot size of the seagrass Halodule wrightii near its southern limit at Rio de Janeiro state, Brazil. Aquat. Bot., v. 65, n. 1/4, p. 47-58, 1999a.

CREED, J. C.; AMADO-FILHO, G. M. Disturbance and recovery of the macroflora of a seagrass (Halodule wrightii Ascherson) meadow in the Abrolhos Marine National Park, Brazil: an experimental evaluation of anchor damage. J. Exp. Mar. Bio. Ecol., v. n. 2, 235, p. 285-306, 1999b.

CREED, J. C. The biodiversity of Brazil's seagrass and seagrass habitats: a first analysis. Biol. Mar. Medit., v. 7, n. 2, p. 207210, 2000a.

CREED, J. C. Epibiosis on cerith shells in a seagrass bed: correlation of shell occupant with epizoite distribution and abundance. Mar. Biol., v. 137, n. 5, p. 775-782, 2000 b.

CREED, J. C. The seagrasses of South America: Brazil, Argentina and Chile. In: GREEN, E. P.; SHORT, F. T. (Eds.). World Atlas of seagrasses. Berkeley: University of California Press, 2003. p. 243-245.

CROWLEY, T. J. Are there any satisfactory geologic analogs for a future greenhouse warming? J. Clim., v. 3, p. 1282-1292, 1990.

CULLEN-UNSWORTH,L.C.; NORDLUND, L. M.; PADDOCK, J.; BAKER, S.; MCKENZIE, L. J.; UNSWORTH, R. K. F. Seagrass meadows globally as a coupled social-ecological system: Implications for human wellbeing. Mar. Pollut. Bull., v. 83, n. 2 , p. $387-397,2014$.

CUMMINS, S. P.; ROBERTS, D. E.; ZIMMERMAN, K. D. Effects of the green macroalga Enteromorpha intestinalis on macrobenthic and seagrass assemblages in a shallow coastal estuary. Mar. Ecol. Prog. Ser., v. 266, p. 77-87, 2004. 
DE LA TORRE-CASTRO, M.; RÖNNBÄCK, P. Links between humans and seagrasses-an example from tropical East Africa. Ocean Coast. Manag., v. 47, n. 7/8, p. 361-387, 2004.

DEN HARTOG, C. Halodule emarginata nov. sp., a new sea-grass from Brazil (Potamogetonaceae). Blumea, v. 18, p. 65-66, 1970.

DEN HARTOG, C. The sea-grasses of Brazil. Acta. Bot. Neerl., v. 21, n. 5 , p. $512-516,1972$.

DEN HARTOG, C.; KUO, J. Taxonomy and biogeography of seagrasses. In: LARKUM, A. W. D.; ORTH, R. J.; DUARTE, C. M. (Eds.) Seagrasses: Biology, ecology and conservation. Dordrecht: Springer, 2006. p. 1-23.

DENNISON, W. C. Environmental problem solving in coastal ecosystems: A paradigm shift to sustainability. Estuar. Coast. Shelf Sci., v. 77, n. 2, p. 185-196, 2008.

DIAS, J. A.; CEARRETA, A.; ISLA, F. I.; MAHIQUES, M. M. Anthropogenic impacts on Iberoamerican coastal areas: Historical processes, present challenges, and consequences for coastal zone management. Ocean Coast. Manag., v. 77, p. 80-88, 2012.

DILLENBURG, S. R.; BARBOZA, E. G.; TOMAZELLI, L. J.; HESP, P. A.; CLEROT, L. C. P.; AYUP-ZOUAIN, R. N. The Holocene Coastal Barriers of Rio Grande do Sul. In: DILLENBURG, S. R.; HESP, P. A. (Eds.). Geology and Geomorphology of Holocene Coastal Barriers of Brazil. New York: Springer, 2009. p. 53-91.

D'INCAO, F. Pesca e biologia de Penaeus paulensis na Lagoa dos Patos. Atlântica, v. 13, n. 1, p. 159-169, 1991.

DOMINGUEZ, J. M. L; BITTENCOURT, A. C. S. P. Regional assessment of long term trends of coastal erosion in Northeastern Brazil. An. Acad. Bras. Ciênc., v. 68, p. 355-371, 1996.

DOMINGUEZ, J. M. L. The coastal zone of Brazil: an overview. J. Coastal Research SI 39: 16-20. (2004).

DOMINGUEZ, J. M. L; The Holocene Coastal Barriers of Rio Grande do Sul. In: DILLENBURG, S. R.; HESP, P. A. (Eds.). Geology and Geomorphology of Holocene Coastal Barriers of Brazil. New York: Springer, 2009. p. 17-51.

DOMNING, D. P. Sirenians, seagrasses and Cenozoic ecological change in the Caribbean. Palaeogeogr. Palaeoclimatol. Palaeoecol., v. 166, n. 1/2, p. 27-50, 2001.

DONEY, S. C.; RUCKELSHAUS, M.; DUFFY, J. E.; BARRY, J. P.; CHAN, F.; ENGLISH, C. A.; GALINDO, H. M.; GREBMEIER, J. M.; HOLLOWED, A. B.; KNOWLTON, N.; POLOVINA, J.; RABALAIS, N. N.; SYDEMAN, W. J.; TALLEY, L. D. Climate change impacts on marine ecosystems. Ann. Rev. Mar. Sci., v. 4, p. 11-37, 2012.

DUARTE, C. M. The future of seagrass meadows. Environ. Conserv., v. 29, n. 2, p. 192-206, 2002.

DUARTE, C. M.; MARBÀ, N.; GACIA, E.; FOURQUREAN, J. W.; BEGGINS, J.; BARRÓN, C.; APOSTOLAK, E. T. Seagrass community metabolism: Assessing the carbon sink capacity of seagrass meadows. Global Biogeochem. Cycles, v. 24, n. $4,2010$.

DUARTE, C. M.; LOSADA, I. J.; HENDRIKS, I. E.; MAZARRUSA, I.; MARBA N. The role of coastal plant communities for climate change mitigation and adaptation. Nature Climate Change 3, 961-968. (2013)

DUTRA, G.; ALLEN, G. R.; WERNER, T.; MCKENNA, S. A. A Rapid Marine Biodiversity Assessment of the Abrolhos Bank, Bahia, Brazil Conservation International. Washington: Center for Applied Biodiversity Science, 2006. 160 p.
FEDOROV, A. V.; PHILANDER, S. G. Is El Niño Changing? Science, v. 288, n. 5473, p. 1997-2002, 2000.

FERREIRA, C. E. L.; GONÇALVES, J. E. A. Community structure and diet of roving herbivorous reef fishes in the Abrolhos Archipelago, south-western Atlantic. J. Fish Biol., V. 69 , p. 1533-1551, 2006.

FERREIRA, C.; HORTA, P. A.; ALMEIDA, G. M.; ZITTA, C. S.; DE M OLIVEIRA, E.; GUEYE, M. B. Y. B.; RODRIGUES, A. C. Anatomical and ultrastructural adaptations of seagrass leaves: an evaluation of the southern Atlantic groups. Protoplasma, v. 251, n. 1, p. 1615-6102-0, 2014.

FLINDT, M. R.; KAMP-NIELSEN, L.; MARQUES, J. C.; PARDAL, M. A.; BOCCI, M.; BENDORICHO, G.; NIELSEN, S. N.; JORGENSEN, S. E. Description of the three shallow estuaries: Mondego river (Portugal), Roskilde Fjord (Denmark) and the Lagoon of Venice (Italy). Ecol. Modell., v. 102, n. 1, p. 17-31, 1997.

FOURQUREAN, J. W.; DUARTE, C. M.; KENNEDY, H.; MARBÀ, N.; HOLMER, M.; MATEO, M. A.; APOSTOLAKI, E. T.; KENDRICK, G. A.; KRAUSEJENSEN, D.; MCGLATHERY, K. J.; SERRANO, O. Seagrass ecosystems as a globally significant carbon stock. Nat. Geosci., v. 5, n. 7, p. 505-509, 2012.

FRANÇA, C. R. C.; PITANGA, M. E.; SILVA, S. L.; ALVES, M. D. O.; ARAÚJO, M. E.; SILVA, S. L.; MAGALHÃES, K. M. Morfologia foliar e densidade da haste de Halodule wrightii (Cymodoceaceae), no litoral de Alagoas, Brasil. Trop. Oceanogr., v. 41, p. 58-66, 2013.

GALVÃO, T.; NOLASCO, M. C. Urbanization and coral reefs in Guarajuba beach, north coast of Bahia, Brazil. Ocean Coast. Manag., v. 77, p. 50-58, 2013.

GARCIA, A. M.; VIEIRA, J. P. Abundância e diversidade da assembleia de peixes dentro e fora de uma pradaria de Ruppia maritima L., no estuário da Lagoa dos Patos (RS - Brasil). Atlântica, v. 19, p. 161-181, 1997.

GARCIA, A. M.; VIEIRA, J. P.; BEMVENUTI, C. E.; GERALDI, R. M. Abundância e diversidade de crustáceos decápodos dentro e fora de uma pradaria de Ruppia maritima L. no estuário da Lagoa dos Patos (RS, Brasil). Nauplius, v. 4, p. 113-128, 1996.

GARREAUD, R. D.; VUILlE, M.; COMPAGNUCCI, R; MARENGO, J. Present-day south american climate. Palaeogeogr. Palaeoclimatol. Palaeoecol., v. 281, n. 3, p. 180195, 2009.

GARRETA, H. P.; ALVES, C. M. R. The Brazilian coastal zone: the main environmental problems and their consequences for human health. Epidemiology, v. 14, n. 5, p. S13, 2003.

GARTHWIN, R. G.; POORE, A. G. B.; VERGÉS, A. Seagrass tolerance to herbivory under the increased ocean temperatures. Mar. Pollut. Bull., v. 83, n. 2, p. 475-482, 2014

GIANASI, B. L.; OLIVEIRA, A. O.; ARAUJO, M. L. V.; COPERTINO, M. S. Utilização de LANDSAT-TM no estudo de uma floração de macroalgas de deriva no Estuário da Lagoa dos Patos (RS, Brasil). In: Anais do XV Simpósio Brasileiro de sensoriamento remoto. São José dos Campos: INPE, 2011. p. 7044-7050.

GRILO, C. F.; NETO, R. R.; VICENTE, M. A.; DE CASTRO, E. V. R.; FIGUEIRA, R. C. L.; CARREIRA, R. S. Evaluation of the influence of urbanization processes using mangrove and fecal markers in recent organic matter in a tropical tidal flat estuary. Appl. Geochem., v. 38, p. 82-91, 2013. 
GRIMM, A. M.; BARROS, V. R.; DOYLE, M. E. Climate variability in Southern South America associated with El Niño and La Niña events. J. Clim., v. 13, p. 35-58, 2000.

HAIMOVICI, M.; CASTELLO, J. P.; VOOREN, C. M. Fisheries. In: SEELIGER, U.; ODEBRECHT, C.; CASTELLO, J. P. (Eds.). Subtropical Convergence Environments: the coast and sea in the Southwestern Atlantic. Berlin: Springer-Verlag, 1997. p. 183-196.

HECK, J. R.; CARRUTHERS, T. J. B.; DUARTE, C. M.; HUGHES, A. R.; KENDRICK, G.; ORTH, R. J.; WILLIAMS, S. W. Trophic transfers from seagrass meadows subsidize diverse marine and terrestrial consumers. Ecosystems, v. 11, n. 7, p. 1198-1210, 2008.

HEMMINGA, M. A.; DUARTE, C. M. Seagrass ecology. Cambridge: Cambridge University Press, 2000. 200 p.

IBAMA. Monitoramento da atividade pesqueira no litoral do Brasil. Relatório Técnico Final do projeto de monitoramento da atividade pesqueira no litoral do Brasil - projeto ESTATPESCA. Brasília: IBAMA, 2006, 328 p.

ICMBIO. Plano de manejo da APA Costa dos Corais. Brasília: Ministério do Meio Ambiente, 2012. 73 p.

IDEMA. Avaliação e ações prioritárias para a conservação da biodiversidade da zona costeira e marinha: caracterização dos ecossistemas costeiros dos Estados Rio Grande do Norte, Ceará e Piauí. Governo do Estado do Rio Grande do Norte (Base de Dados Tropical - BDT), Natal, 1999. 50 p.

KALIKOSKI, D. C.; VASCONCELLOS, M. Case study of the technical, socio-economic and environmental conditions of small-scale fisheries in the estuary of Patos Lagoon, Brazil: a methodology for assessment. Rome: Food and Agriculture Organization of the United Nations, 2012. 199 p.

KEMP, W. M.; BATIUK, R.; BARTLESON, R.; BERGSTROM, P.; CARTER, V.; GALLEGOS, C.; HUNLEY, W.; KARRH, L.; KOCH, E. W.; LANDWEHR, J. M.; MOORE, K. A.; MURRAY, L.; NAYLOR, M.; RYBICKI, N. B.; WILCOX, D. V. Habitat requirements for submerged aquatic vegetation in Chesapeake Bay: Water quality, light regime, and physical-chemical factors. Estuaries, v. 27, n. 3, p. 363377,2004

KEMPF, M. Nota preliminar sobre os fundos costeiros da região de Itamaricá (Norte do Estado de Pernambuco, Brasil). Trab. Oceang. Univ. Fed. Pernamb., v. 9/11, p. 111-124, 1970.

KJERFVE, B. Comparative oceanography of coastal lagoons. In: WOLFE, D. A. (Ed.). Estuarine variability. New York: Academic Press, 1986. p. 63-81.

KOCH, E. V.; SEELIGER, U. Germination ecology of two Ruppia maritima L. populations in Southern Brazil. Aquat. Bot., v. 31, p. 321-327, 1988.

KOCH, D. S.; BAUER, A.; DEL GENIO, G.; FALUVEGI, J. R.; MCCONNELL, S.; MENON, R. L.; MILLER, D.; RIND, R.; RUEDY, G. A.; SCHMIDT, S.; SHINDELL, D. Coupled aerosol-chemistry-climate twentieth century transient model investigation: Trends in short-lived species and climate responses. J. Clim. v. 24, p. 2693-2714, 2011

KOCH, E. V. Beyond light: Physical, geological, and geochemical parameters as possible submersed aquatic vegetation habitat requirements. Estuaries, v. 24, n. 1, p. 1-17, 2001.

KOCH, E. V.; SEELIGER, U. Germination ecology of two Ruppia maritima L. populations in Southern Brazil. Aquat. Bot., v. 31, p. 321-327, 1988.
LABOREL-DEGUEN, F. Nota preliminar sobre a ecologia das pradarias de fanerógamas marinhas nas costas dos estados de Pernambuco e da Paraíba. Trab. Oceang. Univ. Fed. Pernamb., v. 3/4, p. 39-50, 1963

LACERDA, L. D.; RESENDE, C. E. Metals in the seagrass Halodule wrightii Aschers during one growing season. Rev. Bras. Bot., v. 9, p. 87-90, 1986.

LARKUM, A. W. D.; MCCOMB, A. J.; SHEPHERD, S. A. Biology of seagrasses. Amsterdam: Elsevier, 1989. 393 p.

LARKUM A.; ORTH, R. J.; DUARTE, C. M. Seagrasses: biology, ecology and conservation. Dordrecht: Springer, 2006. $691 \mathrm{p}$

LAUER, M.; ASWANI, S. Indigenous knowledge and longterm ecological change: detection, interpretation, and responses to changing ecological conditions in pacific Island Communities. Environ. Manag., v. 45, n. 5, p. $985-$ 997, 2010

LEÃO, R. M.; SECCHIN, N. A.; AMADO-FILHO, G. M.; FRANCINI-FILHO, R. B.; FREITAS, M. O.; MINTEVERA, C. V.; TEIXEIRA, J. B.; THOMPSON, F. L.; DUTRA, G. F.; SUMIDA, P. Y. G.; GUTH, A. Z.; LOPES, R. M.; BASTOS, A. C. Spatial patterns of benthic megahabitats and conservation planning in the Abrolhos Bank. Cont. Shelf Res., v. 70, p. 109-117, 2013.

LEÃO, Z. M. D. A. N.; KIKUCHI, R. K. P. The Abrolhos Reefs of Brazil (Review). Ecol. Stud., v. 144, p. 83-96, 2001.

LIMA, T.; QUINAMO, T. Características Socio-econômocas. In: Gerenciamento Participativo de Estuários e Manguezais. Recife: Editora Universitária da UFPE, 2000. p. 181-225.

LOVELOCK, C. E.; CALliSTER, R. R. J. Blue carbon' projects for the collective good. Carbon Management 4:5, 477-479 (2013)

MAGALHÃES, K. M.; ALVES, M. S. Fanerógamas marinhas do litoral do Estado do Pernambuco. In: TABARELLI, M.; SILVA, J. M. C. (Eds.). Diagnóstico da Biodiversidade de Pernambuco. Recife: SECTMA, 2007, p. 173-181.

MAGAlHÃES, K. M; BORGES, J. C. G.; PITANGA, M. E. Halophila baillonis Ascherson: first population dynamics data for the Southern Hemisphere. An. Acad. Bras. Ciênc., v. 87, n. 2 , p. $861-865,2015$.

MAGAlHÃES， K. M.; CAZUZA， M. S. Distribuição das angiospermas marinhas no litoral do estado de Pernambuco, Brasil. $1^{\circ}$ Parte: Levantamentos de herbário e literatura. Cad. FAFIRE, v. 4, n. 11, p. 20-26, 2005.

MAGALHÃES, K. M.; CONCENTINO, A. M.; ESKINAZILEÇA, E.; FERNANDES, M. B.; REIS, T. N. V.; GUIMARÃES, N. C. L.; RODRIGUES, H. S. Seagrass meadows at the Suape Port area, Pernambuco, Brazil. In: Anais do VI Congresso de Ecologia do Brasil. Fortaleza: Universidade Federal do Ceará, 2003. p. 334-335.

MAGALHÃES, K. M.; ESKINAZI-LEÇA, E. Os prados de fanerógamas marinhas. In: BARROS, H. M.; ESKINAZI-LEÇA, E.; MACEDO, S. J.; LIMA, T. (Eds.). Gerenciamento participativo de estuários e manguezais. Recife: Editora Universitária da UFPE, 2000. p. 39-47.

MAGALHÃES, K. M.; ESKINAZI-LEÇA, E.; MOURA, J. A. M. Biomassa e morfometria da fanerógama marinha Halodule wrightii Ascherson no litoral norte de Pernambuco. Trab. Oceang. Univ. Fed. Pernamb., v. 25, p. 83-92, 1997. 
MAHIQUES, M. M.; BURONE, L.; FIGUEIRA, R. C. L.; LAVENÉRE-WANDERLEY, A. A. O; CAPELLARI, B.; ROGACHESKI, C. E.; BARROSO, C. P.; SANTOS, L. A. S.; CORDERO, L. M.; CUSSIOLI, M. C. Anthropogenic influences in a lagoonal environment: a multiproxy approach at the Valo Grande mouth, Cananéia-Iguape system (SE Brazil). Braz. J. Oceanogr., v. 57, n. 4, p. 325-337, 2009.

MARANGONI, J. C. Subsídios para o gerenciamento das marismas no estuário da Lagoa dos Patos (RS). Tese. Rio Grande, Oceanografia Biológica, FURG, 2008.

MARANGONI, J. C.; COSTA, C. S. B. Natural and anthropogenic effects on salt marsh over five decades in the patos lagoon (Southern Brazil). Braz. J. Oceanogr., v. 57, n. 4, p. 345-350, 2009.

MARENGO, J. A.; JONES, R.; ALVES, L. M.; VALVERDE, M. C. Future change of temperature and precipitation extremes in South America as derived from the PRECIS regional climate modeling system. Int. J. Climatol., v. 29, n. 15, p. 2241-2255, 2009

MARQUES, L. V.; CREED, J. C. Biologia e ecologia das fanerógamas marinhas do Brasil. Oecol. Bras., v. 12, n. 2, p. 315-331, 2008.

MARQUES, L. V.; SHORT, F. T.; CREED, J. C. Sunspots drive seagrasses. Biol. Rhythm Res., v. 46, n. 1, p. 63-68, 2015.

MARTINS, C. D. L.; ARANTES, N.; FAVERI, C.; BATISTA, M. B.; OLIVEIRA, E. C.; PAGLIOSA, P. R.; FONSECA, A. L.; NUNES, J. M. C.; CHOW, F.; PEREIRA, S. B.; HORTA, P. A. The impact of coastal urbanization on the structure of phytobenthic communities in southern Brazil. Mar. Pollut. Bull., v. 64, n. 4, p. 772-778, 2012.

MARTINS, I.; MARQUES, J. C. A model for the growth of opportunistic macroalgae (Enteromorpha sp.) in Tidal Estuaries. Estuar. Coast. Shelf Sci., v. 55, n. 2, p. 247-257, 2002.

MAZO, A. M. M. Distribuição e biomassa da fanerógama submersa Ruppia maritima L. no estuário da Lagoa dos Patos. Tese (Mestrado) - Rio Grande: Universidade Federal do Rio Grande, 1994. 83 f.

MCLEOD, E.; CHMURA, G. L.; BOUILLON, S.; SALM, R.; BJÖRK, M.; DUARTE, C. M.; LOVELOCK, C. E.; SCHLESINGER, W.H.; SILLIMAN, B. R. A blueprint for blue carbon: toward an improved understanding of the role of vegetated coastal habitats in sequestering $\mathrm{CO} 2$. Frontiers in Ecology and the Environment 9:10, 552-560 (2011)

MELLO, G. H. Expansão e estrutura urbana de Santos (SP): aspectos da periferização, da deterioração, da intervenção urbana, da verticalização e da sociabilidade. Tese (Mestrado) - São Paulo: Universidade de São Paulo, 2008. 201 f.

MILLENNIUM ECOSYSTEM ASSESSMENT. Ecosystem and human well-being: biodiversity synthesis. Washington: World Resources Institute, 2005.

MILLY, P. C. D.; DUNNE, K. A.; VECCHIA, A. V. Global pattern of trends in streamflow and water availability in a changing climate. Nature, v. 438, p. 347-350, 2005.

MÖlleR JÚNIOR, O. O.; VAZ, C. A.; CASTELlO, J. P. The effect of river discharge and winds on the interannual variability of the pink shrimp Farfantepenaeus paulensis production in Patos Lagoon. Estuaries Coast., v. 32, n. 4, p. 787-796, 2009.

MUEHE, D. Brazilian coastal vulnerability to climate change. Panam. J. Aquat Sci., v. 5, n. 2, p. 173-183, 2010.
ODEBRECHT, C.; ABREU, P. C.; BEMVENUTI, C. E.; COPERTINO, M.; MUELBERT, J. H.; VIEIRA, J. P.; SEELIGER, U. The Patos Lagoon Estuary: Biotic responses to natural and anthropogenic impacts in the last decades (1979-2008). In: KENNISCH, M.; PAERL, H. (Orgs.). Coastal Lagoons: Critical Habitats of Environmental Change. Boca Raton: Taylor \& Francis /CRC Press, 2010. p. 223-248.

OLIVEIRA, E. C. F.; PIRANI, J. R.; GIULETTI, A. M. The Brazilian seagrasses. Aquat. Bot., v. 16, n. 3, p. 251-267, 1983.

ORTH, R. J.; CARRUTHERS, T. J. B.; DENNISON, W. C.; DUARTE, C. M.; FOURQUREAN, J. W.; HECK, K. L.; HUGHES, A. R.; HENDRICK, G. A.; KENWORTHY, W. J.; OLYARNIK, S.; SHORT, F. T.; WAYCOTT, M.; WILLIAMS, S. L. A global crisis for seagrass ecosystems. BioScience, v. 56, n. 12, p. 987-996, 2006.

ORTH, R. J.; KENDRICK, G. A.; MARION, S. C. Posidonia australis seed predation in seagrass habitats of Two Peoples Bay, Western Australia, Aquat. Bot., v. 86, n. 1, p. 83-85, 2007.

PAIVA, M. P.; NOMURA, H. Sobre a produção pesqueira de alguns currais-de-pesca do Ceará: dados de 1962 a 1964. Arq. Cienc. Mar., v. 5, n. 2, p. 175-214, 1965.

PAPINI, A.; SORDO, L.; MOSTI, S. Surface interactions of the epiphytic macroalga Hincksia mitchelliae (Phaeophyceae) with the shoalgrass Halodule wrightii (Cymodoceaceae). J. Phycol., v. 47, n. 1, p. 118-122, 2011.

PAULA, A. F.; FIGUEIREDO, M. A. D.; CREED, J. C. Structure of the macroalgal community associated with the seagrass Halodule wrightii Ascherson in the Abrolhos Marine National Park, Brazil. Bot. Mar., v. 46, n. 5, p. 413-424, 2003.

PAULA D. P.; DIAS, J. M. A.; FERREIRA, O; MORAIS, J. O. High-rise development of the sea-front at Fortaleza (Brazil): Perspectives on its valuation and consequences. Ocean Coast. Manag., v. 77, p. 14-23, 2013.

PEREIRA, E. B.; MARTINS, F. R.; PES, M. P.; SEGUNDO, E. I. C.; LYRA, A. A. The impacts of global climate changes on the wind power density in Brazil. Renew. Energ., v. 49, p. 107-110, 2013.

PERGENT, M. C.; PERGENT, G. Spatio-temporal dynamics of Posidonia oceanica beds near a sewage outfall (Mediterranean-France). In: KUO, J.; PHILIPS, R. C.; WALKER, D. I.; KIRKMAN, H. (Eds.). Seagrass Biology: proceedings of an international workshop. Rottnest Island, 1996. p. 299-306.

PITANGA, M. E.; MONTES, M. J. F.; MAGALHÃES, K. M.; REIS, T. N. V. Quantification and classification of the main environmental impacts on a Halodule wrightii seagrass meadow on a tropical island in northeastern Brazil. An. Acad. Bras. Ciênc., v. 84, n. 1, p. 35-42, 2012.

PREEN, A. R.; LEE LONG, W. J.; LEE COLES, R. G. Flood and cyclone related loss, and partial recovery, of more than $1000 \mathrm{~km} 2$ of seagrass in Hervey Bay, Queensland, Australia. Aquat. Bot., v. 52, n. 1/2, p. 3-17, 1995.

REBOUÇAS, S. C. Uso inteligente da água. São Paulo: Escrituras, 2004.

REIS, E. G. An assessment of exploitation of the white croaker Micropogonias furnieri (Pisces, Sciaenidae) by the artisanal and industrial fisheries in coastal waters of southern Brazil. $\mathrm{PhD}$ (Thesis). Norwich, University of EastAnglia, England, 1992. $223 \mathrm{f}$. 
ROSA, L. C.; BEMVENUTI, C. E. Temporal variability of the estuarine macrofauna of the Patos Lagoon, Brazil. Rev. Biol. Mar. Oceanogr., v. 41, n. 1, p. 1-9, 2006.

RUAS, V. M.; RODRIGUES, M. A.; DUMONT, L. F. C.; D'INCAO, F. Habitat selection of the pink shrimp Farfantepenaeus paulensis and the blue crab Callinectes sapidus in an estuary in southern Brazil: influence of salinity and submerged seagrass meadows. Nauplius, v. 22, n. 2, p. 113-125, 2014

SALLES, F. J. P.; BENTES, F. C. M.; SANTOS, J. A. Catálogo de Estações Maregráficas. Fundação de Estudos do Mar. Rio de Janeiro: FEMAR, 2000.

SAUNDERS, M. I.; LEON, J. X.; CALLAGHAN, D. P.; ROELFSEMA, C. M; HAMYLTON, S.; BROWN, C. J.; BALDOCK, T.; GOLSHANI, A.; PHINN, S. R.; LOVELOCK, C. E.; HOEGH-GULDBERG, O.; WOODROFFE, C. D.; MUMBY, P. J. Interdependency of tropical marine ecosystems in response to climate change. Nat. Clim. Chang., v. 4, p. 724-729, 2014.

SEDDON, S.; CHESIRE, A. C. Photosynthetic response of Amphibolis antarctica and Posidonia australis to temperature and desiccation using chlorophyll fluorescence. Mar. Ecol. Prog. Ser., v. 220, p. 119-130, 2001.

SEDDON, S. Causes and ecological consequences of the Spencer Gulf seagrass dieback. PhD thesis. Adelaide, University of Adelaide, 2000.

SEELIGER, U.; COSTA, C. B. S.; ABREU, P. C. Primary production cycles. In: SEELIGER, U.; ODEBRECHT, C.; CASTELLO, J. P. (Eds.). Subtropical Convergence Environments: The Coast and Sea in the Southwestern Atlantic. New York: Springer-Verlag, 1997a. p. 65-70.

SEELIGER, U.; COSTA, C. S. B. Natural and human impact. In: SEELIGER, U.; ODEBRECHT, C.; CASTELLO, J. P. (Eds.). Subtropical Convergence Environments: The Coast and Sea in the Southwestern Atlantic. New York: Springer-Verlag, 1997b. p. 197-203.

SEELIGER, U.; ODEBRECHT, C. O Estuário da Lagoa dos Patos: um século de transformações. Rio Grande: FURG, 2010. 180 p.

SHEPHERD, S. A.; ROBERTSON, E. L. Regional studiesseagrasses of South Australia, Western Victoria and Bass Strait. In: LARKUM, A. W. D.; MCCOMB, A. J.; SHEPHERD, S. A. (Eds.). Biology of Seagrasses: A Treatise on the Biology of Seagrasses with Special References to the Australian Region. Amsterdam: Elsevier, 1989. p. 211-229.

SHORT, F. T.; CARRUTHERS, T.; DENNISON, W.; WAYCOTT, M. Global seagrass distribution and diversity: A bioregional model. J. Exp. Mar. Biol. Ecol. v. 350, n. 1, p. 3-20, 2007.

SHORT, F. T.; MCKENZIE, L. J.; COLES, R. G.; GAECKLE, J. L. SeagrassNet Manual for Scientific Monitoring of Seagrass Habitat - Caribbean. Durham: University of New Hampshire, 2005. $74 \mathrm{p}$.

SHORT, F. T.; MCKENZIE, L. J.; COLES, R. G.; VIDLER, K. P.; GAECKLE, J. L. SeagrassNet: Manual for scientific monitoring of seagrass habitat. New Hampshire: Wordwide: 2006. 75 p.

SHORT, F. T.; MOORE, G. E.; PEYTON, K. A. Halophila ovalis in the Tropical Atlantic Ocean. Aquat. Bot., v. 93, n. 3, p. 141146,2010

SHORT, F. T.; NECKLES, H. A. The effects of global climate change on seagrasses. Aquat. Bot., v. 63, p. 169-196, 1999.
SHORT, F.T.; WYLLIE-ECHEVERRIA, S. Natural and humaninduced disturbance of seagrasses. Environ. Conserv., v. 23, n. 1, p. 17-27, 1996.

SILBERSTEIN, K.; CHIFFINGS, A. W.; MCCOMB, A. J. The loss of seagrass in Cockburn sound, Western Australia. III. The effect of epiphytes in productivity of Posidonia australis Hook. Aquat. Bot., v. 24, n. 4, p. 355-317, 1986.

SILVA, E. T. Modelo ecológico de fundos vegetados dominados por Ruppia maritima (Potamogetonacea) do estuário da Lagoa dos Patos - RS. MSc Thesis. Porto Alegre, Universidade Federal do Rio Grande do Sul, 1995. 210 f.

SILVA, E. T.; ASMUS, M. L. A dynamic simulation model of the widgeon grass Ruppia maritima and its epiphytes in the estuary of the Patos Lagoon, RS, Brazil. Ecol. Modell., v. 137, p. 161-179, 2001.

SORDO, L. Alterações na estrutura e funcionamento de um banco de Halodule wrightii (Cymodoceaceae) durante um florescimento massivo de epifitas na baia de Paranagua (Parana, Brasil). MSc thesis. Curitiba, Universidade Federal do Paraná, 2008. 60 f.

SORDO, L.; FOURNIER, J.; OLIVEIRA, V. M.; GERN, F.; PANIZZA, A. C.; LANA, P. C. Temporal variations in morphology and biomass of vulnerable Halodule wrightii meadows at their southernmost distribution limit in the southwestern Atlantic. Bot. Mar., v. 54, n. 1, p. 13-21, 2011.

SOUSA, P. H. G. O.; SIEGLE, E.; TESSLER, M. G. Vulnerability assessment of Massaguaçú beach (SE Brazil). Ocean Coast. Manag., v. 77, p. 24-30, 2013.

SOUZA-FILHO, P. W. M. Costa de manguezais de macromaré da Amazônia: cenários morfológicos, mapeamento e quantificação a partir de dados de sensores remotos. Rev. Bras. Geof., v. 23, n. 4, p. 427-435, 2005.

SOUZA-FILHO, P. W. M., LESSA, G. C., COHEN, M. C. L., COSTA, F. R., LARA, R. J. The subsiding macrotidal barrier estuarine system of the Eastern Amazon Coast, Northern Brazil. In: DILLENBURG, S. F.; HESP, P. A. (Eds.). Geology and Geomorphology of Holocene coastal barriers of Brazil. New York: Springer, 2009. p. 347-375.

TESSLER, M. G.; FIGUEIRA, R. C. L.; MAHIQUES, M. M.; FUKUMOTO, M. M.; CIAPINA, E. M. P. Sedimentation rates and contamination levels by heavy metals at the shallow sedimentary columns from Santos Estuary and Bay, SP, Brazil. J. Coastal Res., v. SI39, p. 713-717, 2006.

TIMMERMANN, A.; LATIF, M.; BACHER, A.; OBERHUBER, J.; ROECKNER, E. Increased El Niño frequency in a climate model forced by future greenhouse warming. Nature, v. 398, p. 694-696, 1999.

TOMAZELLI, L. J.; DILLENBURG, S. R.; VILLWOCK, J. A. Late Quaternary geological history of Rio Grande do Sul coastal plain, southern Brazil. Rev. Bras. Geoc., v. 30, n. 3, p. $470-472,2000$.

TRENBERTH, K. E.; JONES, P. D.; AMBENJE, P.; BOJARIU, R.; EASTERLING, D.; KLEIN, T.; PARKER, D.; RENWICK, J.; RUSTICUCCI, M.; SODEN, B.; ZHAI, P. Observations: Surface and Atmospheric Climate Change. In: SOLOMON, S.; QIN, D.; MANNING, M.; CHEN, Z.; MARQUIS, M.; AVERYT, K. B.; TIGNOR, M.; MILLER, H. L. (Eds.). Climate Change 2007: The Physical Science Basis. Contribution of Working Group I to the Fourth Assessment Report of the Intergovernmental Panel on Climate Change. New York: Cambridge University Press. 2007. p. 235-336. 
TUYA, F.; HAROUN, R.; ESPINO, F. Economic assessment of ecosystem services: Monetary value of seagrass meadows for coastal fisheries. Ocean Coast. Manag., v. 96, p. 181187,2014

UNSWORTH, R. K. F.; CULLEN, L. C.; PRETTY, J. N.; SMITH, D. J.; BELL, J. J. Economic and subsistence values of the standing stocks of seagrass fisheries: potential benefits of no-fishing marine protected area management. Ocean Coast. Manag., v. 53, p. 218-224, 2010.

UNSWORTH, R. K. F.; COLLIER, C. J.; HENDERSON, G. M.; MCKENZIE, L. J. Tropical seagrass meadows modify seawater carbon chemistry: implications for coral reefs impacted by ocean acidification. Environ. Res. Lett., v. 7, n. 2, p. 24-26, 2012.

UNSWORTH, R. K. F.; VAN KEULEN, M.; COLES, R. G. Seagrass meadows in a globally changing environment. Mar. Pollut. Bull., v. 83, n. 2, p. 383-386, 2014.

VASSALLO, P.; PAOLI, C.; ROVERE, A.; MONTEFALCONE, M.; MORRI, C.; BIANCHI, C. N. The value of the seagrass Posidonia oceanica: a natural capital assessment. Mar. Pollut. Bull., v. 75, n. 1/2, p. 157-167, 2014.
WAYCOTT, M.; DUARTE, C. M.; CARRUTHERS, T. J. B.; ORTH, R. J.; DENNISON, W. C.; OLYARNIK, S.; CALLADINI, A.; FOURQUREAN, J. M.; HECK JÚNIOR, K. L.; HUGHES, A. R.; KENDRICK, G. A.; KENWORTHY, W. J.; SHORT, F. T.; WILLIAMS, S. Accelerating loss of seagrasses across the globe threatens coastal ecosystems. Proc. Natl. Acad. Sci. U. S. A., v. 106, n. 30, p. 12377-12381, 2009.

WAYCOTT, M.; FRESHWATER, D. W.; YORK, R. A.; CALLADINE, A.; KENWORTHY, W. J. Evolutionary trends in the seagrass genus Halophila (Thouars): insights from molecular phylogeny. Bull. Mar. Sci., v. 71, n. 3, p. 1299-1308, 2002.

YAAKUB, S. M.; CHEN, E.; BOUMA, T. J.; ERFTEMEIJER, P. L. A.; TODD, P. A. Chronic light reduction reduces overall resilience to additional shading stress in the seagrass Halophila ovalis. Mar. Pollut. Bull., v. 83, n. 2, p. 467-474, 2014.

YEH, S. W.; KUG, J. S.; DEWITTE, B.; KWON, M. H.; KIRTMAN, B. P.; JIN, F. F. El Niño in a changing climate. Nature, v. 461, p. 511-514, 2009. 
